\title{
Model Assessment of Protective Barrier Designs
}

\author{
M. J. Fayer \\ W. Conbere \\ P. R. Heller \\ G. W. Gee
}

November 1985

Prepared for the U.S. Department of Energy under Contract DE-AC06-76RLO 1830

Pacific Northwest Laboratory

Operated for the U.S. Department of Energy by Battelle Memorial Institute 


\title{
DISCLAIMER
}

This report was prepared as an account of work sponsored by an agency of the United States Government. Neither the United States Government nor any agency thereof, nor any of their employees, makes any warranty, express or implied, or assumes any legal liability or responsibility for the accuracy, completeness, or usefulness of any information, apparatus, product, or process disclosed, or represents that its use would not infringe privately owned rights. Reference herein to any specific commercial product, process, or service by trade name, trademark, manufacturer, or otherwise, does not necessarily constitute or imply its endorsement, recommendation, or favoring by the United States Government or any agency thereof. The views and opinions of authors expressed herein do not necessarily state or reflect those of the United States Government or any agency thereof.

\author{
PACIFIC NORTHWEST LABORATORY \\ operated by \\ BATTELLE \\ for the \\ UNITED STATES DEPARTMENT OF ENERGY \\ under Contract DE-AC06-76RLO 1830
}

\begin{tabular}{|c|c|}
\hline \multicolumn{2}{|c|}{ Printed in the United States of America } \\
\hline \multirow{2}{*}{\multicolumn{2}{|c|}{$\begin{array}{c}\text { Available from } \\
\text { National Technical Information Service }\end{array}$}} \\
\hline & \\
\hline \multicolumn{2}{|c|}{$\begin{array}{l}\text { National Technical Information Service } \\
\text { United States Department of Commerce }\end{array}$} \\
\hline \multicolumn{2}{|c|}{ S285 Port Royal Road } \\
\hline \multicolumn{2}{|c|}{ Springfield, Virginia 22161} \\
\hline \multirow{2}{*}{\multicolumn{2}{|c|}{$\begin{array}{l}\text { NTIS Price Codes } \\
\text { Microfiche A01 }\end{array}$}} \\
\hline & \\
\hline \multicolumn{2}{|c|}{ Printed Copy } \\
\hline & Price \\
\hline Pages & Codes \\
\hline $001-025$ & A02 \\
\hline 026-050 & $\mathrm{A} 03$ \\
\hline $051-075$ & A04 \\
\hline $076-100$ & A05 \\
\hline $101-125$ & A06 \\
\hline $126-150$ & A07 \\
\hline $151-175$ & $\mathrm{~A} 08$ \\
\hline $176-200$ & A09 \\
\hline $201-225$ & A010 \\
\hline $226-250$ & A011 \\
\hline $251-275$ & A012 \\
\hline $276-300$ & A013 \\
\hline
\end{tabular}


MODEL ASSESSMENT OF PROTECTIVE

BARRIER DESIGNS
M. J. Fayer
W. Conbere
P. R. Heller
G. W. Gee

November 1985

Prepared for

the U.S. Department of Energy

under Contract DE-AC06-76RLO 1830

Pacific Northwest Laboratory

Richl and, Washington 99352 
.

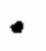

$\checkmark$ 


\section{ACXNOWLEDGMENTS}

This study was supported by the U.S. Department of Energy's Hanford Defense Waste Protective Barriers Program. We wish to acknowledge the contributions of several Rockwell Hanford Operations personnel for their helpful suggestions during the course of this study: Mel Adams, Steve Phillips, Dick Wing, and Cliff Meinhardt. We also wish to acknowledge Dennis Myers and his staff for the extensive sampling and sieve analysis of Hanford site soils. We also thank those at Pacific Northwest Laboratory who provided support on this study: Jim Hartley for program management, Tim Jones for peer review, Dartha Simpson for editing, and Pat Young and Diedre McNeill and their staff for word processing. 


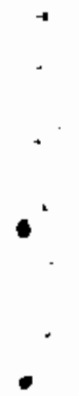


SUMMARY

A protective barrier is being considered for use at the Hanford site to enhance the isolation of previously disposed radioactive wastes from infiltrating water, and plant and animal intrusion. This study is part of a research and development effort to design barriers and evaluate their performance in preventing drainage. A fine-textured soil (the Composite) was located on the Hanford site in sufficient quantity for use as the top layer of the protective barrier. A number of simulations were performed by Pacific Northwest Laboratory to analyze different designs of the barrier using the Composite soil as well as the finer-textured Ritzville silt loam and a slightly coarser soil (Coarse). Design variations included two rainfall rates $(16.0$ and $30.1 \mathrm{~cm} / \mathrm{yr})$, the presence of plants, gravel mixed into the surface of the topsoil, an impermeable boundary under the topsoil, and moving the waste form from 10 to $20 \mathrm{~m}$ from the barrier edge. The final decision to use barriers for enhanced isolation of previously disposed wastes will be subject to decisions resulting from the completion of the Hanford Defense Waste Environmental Impact Statement, which addresses disposal of Hanford defense high-level and transuranic wastes.

The one-dimensional simulation results indicate that each of the three soils, when used as the top layer of the protective barrier, can prevent drainage provided plants are present. Without plants, the Composite soil drained 0.4 and $3.7 \mathrm{~cm} / \mathrm{yr}$ in the dry and wet years, respectively. The Ritzville allowed no drainage in either year, while the coarse soil had $3.1 \mathrm{~cm}$ of drainage in the wet year. Small differences in soil hydraulic properties had large effects on drainage, suggesting the importance of hydraulic property characterization.

Gravel amendments to the upper $30 \mathrm{~cm}$ of soit (without plants) reduced evaporation and allowed more water to drain. Drainage through the composite increased to 1.7 and $7.8 \mathrm{~cm} / \mathrm{yr}$ in the dry and wet years, respectively, while the Ritzville drained $1.8 \mathrm{~cm} / \mathrm{yr}$ during the year. Varying the thickness of the soil/gravel mix layer from 7.5 to $30.0 \mathrm{~cm}$ had $1 \mathrm{ittle}$ effect on the amount of drainage. 
For the Composite soil with gravel added to the top $30 \mathrm{~cm}$ and no plants, the presence of an impermeable layer under the soil layer resulted in the formation of a water table above the impermeable layer: $80 \mathrm{~cm}$ in the dry year and $124 \mathrm{~cm}$ in the wet year (measured on January 1 ).

Two-dimensional simulation results indicated that after 500 years, under the given conditions, water infiltrating at the edge of the barrier would flow toward a waste form located $10 \mathrm{~m}$ from the barrier edge. A waste form located $20 \mathrm{~m}$ from the barrier edge would not be in the major water flow path. 


\section{CONTENTS}

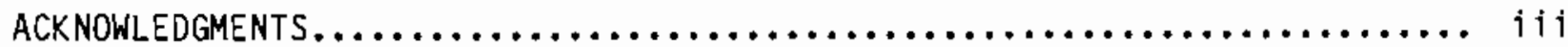

SUMMARY......................................... v

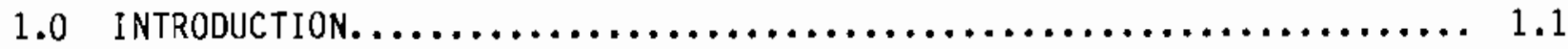

2.0 DESCRIPTION OF ONE-DIMENSIONAL SIMULATIONS................ 2.1

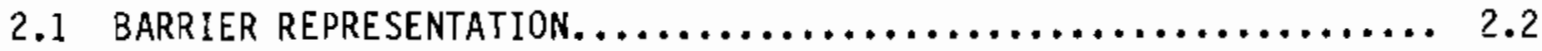

2.2 SOIL PROPERTIES.............................. 2.2

2.3 PLANTS ..................................... 2.7

2.4 INITIAL CONDITIONS $\ldots \ldots \ldots \ldots \ldots \ldots \ldots \ldots \ldots \ldots \ldots \ldots \ldots \ldots \ldots \ldots \ldots$

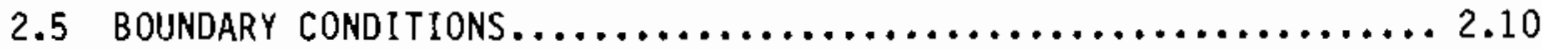

3.0 RESULTS OF ONE-DIMENSIONAL SIMULATIONS $\ldots \ldots \ldots \ldots \ldots \ldots \ldots \ldots \ldots \ldots \ldots \ldots$

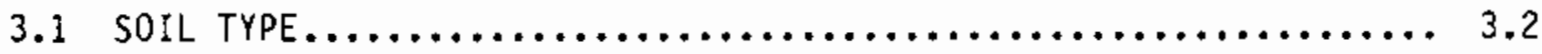

3.2 GRAVEL MIX ADDITION........................... 3.3

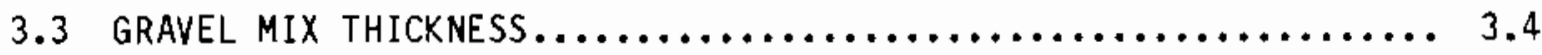

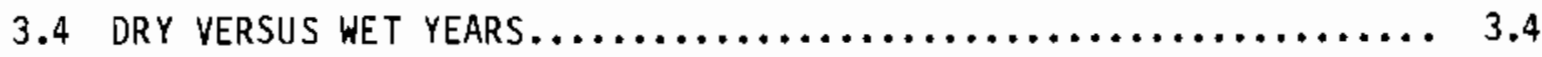

3.5 PLANTS VERSUS NO PLANTS $\ldots \ldots \ldots \ldots \ldots \ldots \ldots \ldots \ldots \ldots \ldots \ldots \ldots \ldots \ldots$

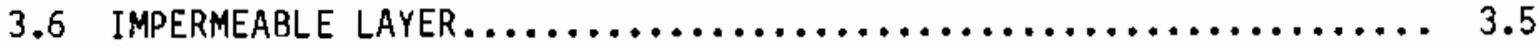

4.0 DESCRIPTION OF TWO-DIMENSIONAL SIMULATIONS $\ldots \ldots \ldots \ldots \ldots \ldots \ldots \ldots \ldots \ldots . \ldots$

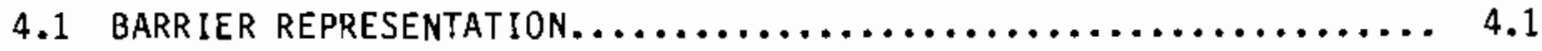

4.2 INITIAL AND BOUNDARY CONDITIONS $\ldots \ldots \ldots \ldots \ldots \ldots \ldots \ldots \ldots \ldots \ldots \ldots . . \ldots \ldots$

5.D RESULTS OF THO-DIMENSIONAL SIMULATIONS $\ldots \ldots \ldots \ldots \ldots \ldots \ldots \ldots \ldots \ldots \ldots$

6.0 CONCLUSIONS AND RECOMMENDATIONS $\ldots \ldots \ldots \ldots \ldots \ldots \ldots \ldots \ldots \ldots \ldots \ldots \ldots \ldots$

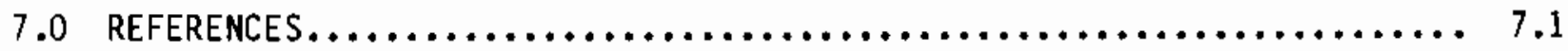

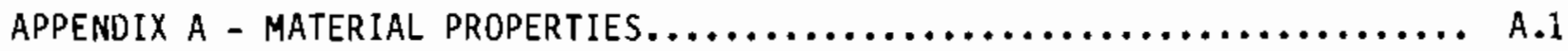

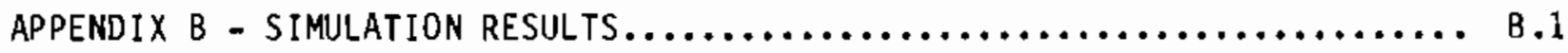




\section{FIGURES}

2.1 Artist Conception of the Barrier System Being Considered for Location over Single-Shelt Waste Tanks................... 2.1

2.2 Node Spacing for the One-Dimensional Simulations.............. 2.3

2.3 Moisture Characteristic Curves for Three Soils and Grave1....... 2.4

2.4 Hydraulic Conductivity Functions for Three Soits and Grave1...... 2.5

2.5 Moisture Characteristic Curves for Two Soils with and Without Gravel Added......................................... 2.6

2.6 Hydraulic Conductivity Functions for Two Soils with and Without Gravel Added................................ 2.7

2.7 Cheatgrass Transpiration Function....................... 2.9

3.1 Year-End Suction Head Profiles for the Ritzville Soil and the Wet Rain Year....................................... 3.6

4.1 Two-Dimensiona? Representation of the Protective Barrier........ 4.2

4.2 Finite Element Grid for the Two-Dimensional Simulations......... 4.3

5.1 Total Head Profile at the End of 500 Years when the Waste Form is Located $20 \mathrm{~m}$ from the Barrier Edge.................... 5.1

5.2 Volumetric Moisture Content Profile at the End of 500 Years when the Waste Form is Located $20 \mathrm{~m}$ from the Barrier Edge........... 5.2

5.3 Total Head Profile at the End of 500 Years when the Waste Form is Located $10 \mathrm{~m}$ from the Barrier Edge..................... 5.3

5.4 Volumetric Moisture Content Profile at the End of 500 Years when the Waste Form is Located $10 \mathrm{~m}$ from the Barrier Edge........... 5.4

5.5 Total Head Profiles at the End of 500 Years in the Vicinity of the waste Form.................................... 5.5

A.1 Map of the 200 -Area Sampling Sites....................... A.2 


\section{TABLES}

2.1 Maximum Rooting Depth During the Growing Season................ 2.9

2.2 'Average Rain Year' Constructed from the Hanford

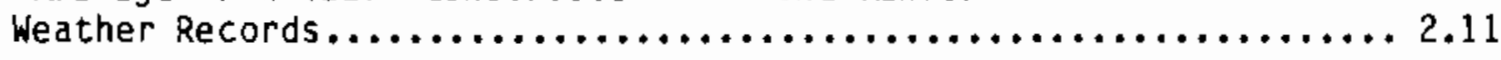

3.1 One-Dimensional Simulation Drainage Results................. 3.2

A.1 Water Retention Data for Hanford Soil Samples................... A.4

A.2 Hydraulic Conductivity for Hanford soil Samples................... A.5

A.3 Particle Size for Hanford Soit Samples....................... A.6

A.4 Gravel Moisture Characteristic Data........................ A.8

B.1 Simulation Run Identification.............................. B

B.2 Final Simulation Year Results........................... 8.2 
, $\bullet$ . , 


\subsection{INTRODUCTION}

Radioactive waste on the Hanford site near Richland, Washington, must be stored and isolated from the component of precipitation that becomes recharge to the local water table. One method that is being considered to enhance the isolation of wastes buried or stored just below ground level would be to place a multilayer barrier over the waste site to prevent drainage of infiltrating water. Such a barrier or cover would be composed of a layer of fine soil on top of a layer of coarse rock fragments (thus the label 'multilayer'). This type of barrier works by storing water from precipitation events so that the water can be evaporated and/or transpired at a later time. Drainage can be prevented if the cover is properly designed. For this report, drainage prevention is defined as 1 imiting the drainage rate to $<0.1 \mathrm{~cm} / \mathrm{yr}$. Whether drainage is prevented mainiy depends on the hydraulic properties of the material, the amount of precipitation, and the plant cover. The physics of the problem are well understood, and experimental observations have confirmed the multilayer concept (Miller and Bunger 1963; Unger 1971). The remaining question is how to design the barrier (e.g., soil type, thickness) to prevent drainage.

In this report, we analyzed several components of a potential barrier design. Specifically, we used the one-dimensional soil water flow code UNSAT-H (Fayer and Gee 1985) to simulate drainage through the barrier when we varied the soil type, mixed gravel into the surface soil layer, and changed the climate and plant presence. Using the predicted drainage rates for the various configurations, we can design the barrier to prevent drainage.

The distance between the waste form and the barrier edge will determine whether water that infiltrates the area surrounding the barrier reaches the waste form. For this type of problem, we used the two-dimensional flow code UNSAT2 (Numan et a 1. 1974) to look at the cases where the barrier edge is 10 and $20 \mathrm{~m}$ from the waste form. Again, the goal is to optimize the barrier design to prevent drainage. 


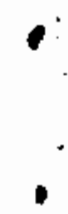

4 


\subsection{DESCRIPTION OF ONE-DIMENSIONAL SIMULATIONS}

The present conceptual design of the protective barrier is illustrated in Figure 2.1. A 1.5-m-thick layer of fine soil will be placed over a 3.6 -m-thick layer of gravel that is $10-$ to $25-\mathrm{cm}$ dia. A $0.3-\mathrm{m}$-thick layer of intermediatesized material will be placed between the soil and gravel to prevent movement of the fine soil into the gravel. The entire system, sometimes referred to as the 'multilayer barrier', is designed to limit the amount of drainage. The barrier works by retarding unsaturated flow in the downward direction, which in turn keeps most of the moisture near the soil surface where it can be evaporated and/or transpired (Miller and Bunger 1963; Unger 1971).

One important assumption that can be verified only through future experimental work is that flow through a well-designed barrier is essentially onedimensional, especially through the gravel layer. Hill and Parlange (1972) observed that saturated flow through layered systems is unstable at the interface between a fine-textured upper layer and a coarse-textured lower layer (similar to the protective barrier). This instability resulted in 'fingering',

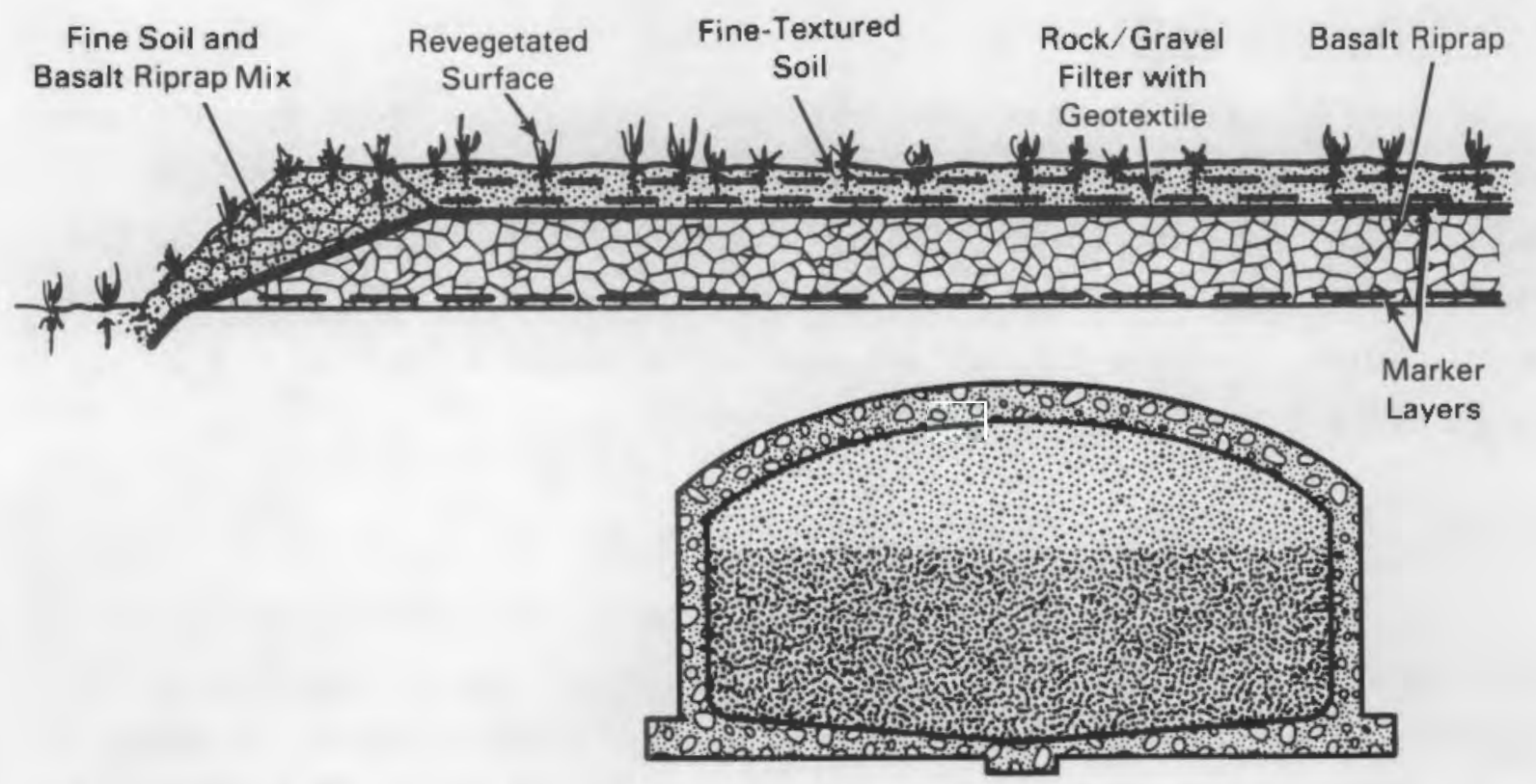

FIGURE 2.1. Artist Conception of the Barrier System Being Considered for Location over Single-Shell Waste Tanks 
in which only a small portion of the underlying coarse layer was part of the flow zone. In this type of situation, a smaller amount of water can travel deeper than expected. We did not simulate this three-dimensional effect; further detailed study is needed. For the protective barrier, this situation will only arise in barrier configurations in which drainage is likely, when soil at the interface is nearly saturated. Evaporation and water uptake by plants should, in most cases, greatly reduce the potential for saturated conditions to exist in the soil profile.

The purpose of this study is to determine the equilibrium drainage rate through the protective barrier given different barrier designs, materials, and climates. Drainage through the protective barrier was simulated using the one-dimensional finite difference code UNSAT-H (Fayer and Gee 1985). We assumed that flow (1iquid and vapor) was one-dimensional, isothermal, and nonhysteretic. The parameters that were varied include soil type, gravel additions to the $30-m$ surface of soil, thickness of the soil receiving the gravel additions, total rainfall, plant presence on the barrier, and placement of an impermeable layer just below the soil layer.

\subsection{BARRIER REPRESENTATION}

We used 37 nodes for the one-dimensional simulations (node center elevations are indicated in Figure 2.2). There were two exceptions: for the simulations of 7.5- and 15-cm-thick soil/gravel mix layers, we increased the node density in the vicinity of the interface between the soil/gravel mix and the soil below. For the simulations with an impermeable layer at $1.5 \mathrm{~m}$, we used 25 nodes (see Figure 2.2).

\subsection{SOIL PROPERTIES}

Three soils were tested for their potential as the top barrier layer: Ritzville silt loam; a fine-textured soil that we call the Composite; and a slightly coarser soil, which we call Coarse. In the vicinity of the Hanford site, the Ritzville soil is probably the finest-textured soil of significant quantity. Unfortunately, this soil is located at some distance from the actual 


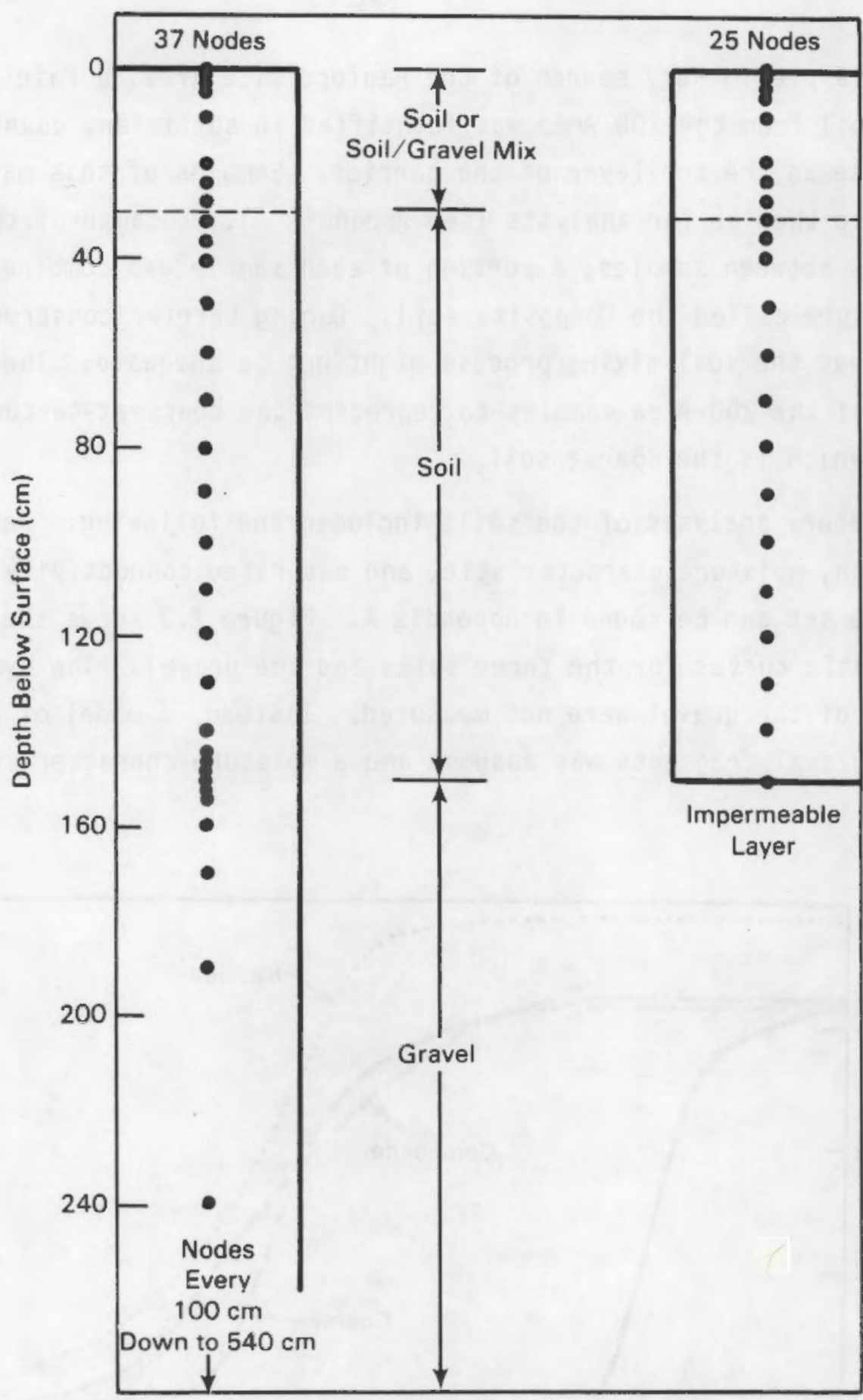

FIGURE 2.2. Node Spacing for the One-Dimensional Simulations

barrier sites, and trucking costs would be high. Ritzville soil was included in this study to show the performance of the barrier with the finest-textured soil available. 
After a preliminary search of the Hanford site area, a fairly finetextured soil from the 200 Area was identified in sufficient quantity for possible use as the top layer of the barrier. Samples of this material were brought into the lab for analysis (see Appendix A). Because of the slight differences between samples, a portion of each sample was combined into a single mixture called the Composite soil. During barrier construction, we realized that the soil-mixing process might not be adequate. Therefore, we chose one of the 200-Area samples to represent the coarsest-textured material expected, which is the Coarse soil.

Laboratory analyses of the soils included the following: particle-size distribution, moisture characteristic, and saturated conductivity. The entire data set can be found in Appendix A. Figure 2.3 shows the moisture characteristic curves for the three soils and the gravel. The hydraulic properties of the gravel were not measured. Instead, a model of 1-cm-dia spherical gravel fragments was assumed and a moisture characteristic

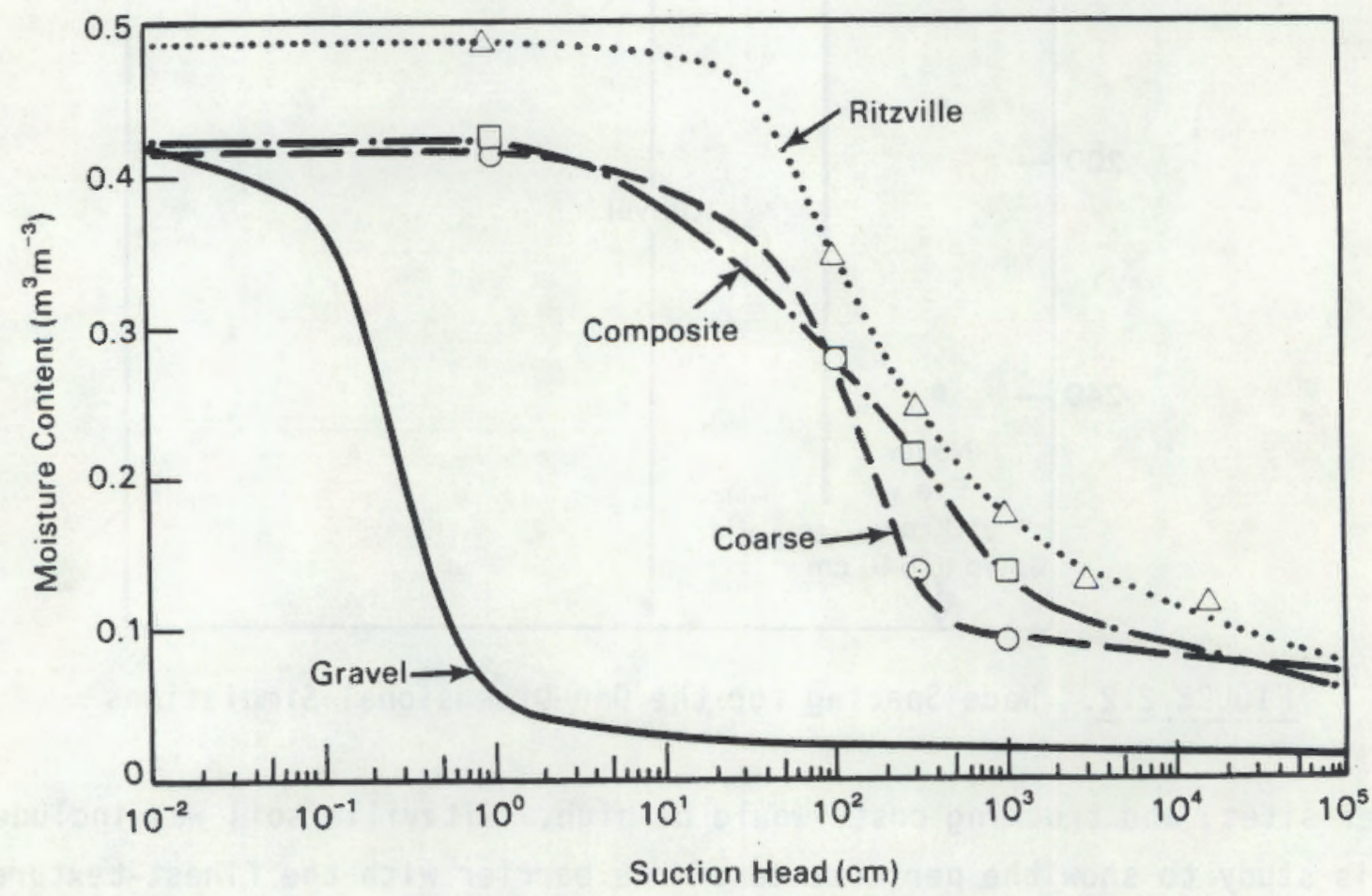

FIGURE 2.3. Moisture Characteristic Curves for Three Soils and Gravel 
constructed (see Appendix A). The unsaturated hydraulic conductivity function for each soil and the gravel was calculated using the program HYDRAK (Bond et al. 1984). HYDRAK calculates the hydraulic conductivity function using the method of Millington and Quirk (1961), which requires knowledge of the moisture characteristic and the saturated conductivity. Figure 2.4 shows the calculated functions for the three soils and the gravel. Although there were no measurements of the gravel conductivity, there are three data points (in Figure 6 of Miller and Bunger 1963) for gravel 6 to $13 \mathrm{~mm}$ in diameter. Those points have

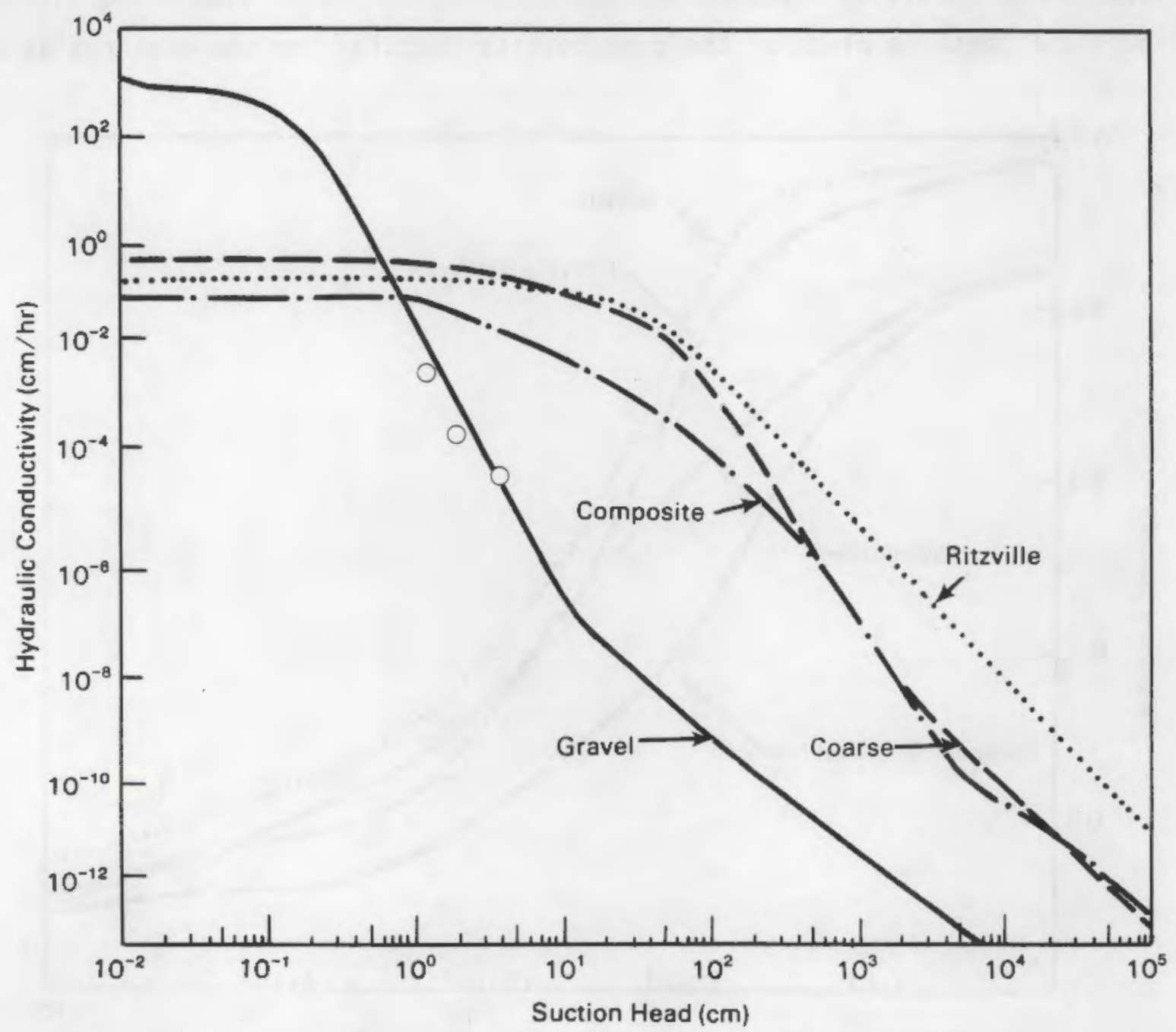

FIGURE 2.4. Hydraulic Conductivity Functions for Three Soils and Gravel (The three gravel data points are from Miller and Bunger 1963.) 
been included in Figure 2.4 to show how the calculated conductivity function for gravel compares with some measured data.

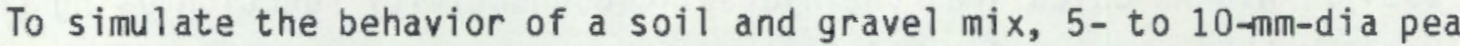
gravel (15 wt\%) was mixed with the Composite and Ritzville soils. The moisture characteristic and saturated conductivity were then measured for the mixtures. The resulting characteristic curves are plotted in Figure 2.5 along with those of the pure soils. Note that the addition of gravel reduces the amount of water held at any particular value of suction head. As before, the unsaturated hydraulic conductivity function for the mixtures was calculated using HYDRAK. Figure 2.6 contains plots of the conductivity function for the mixtures as well

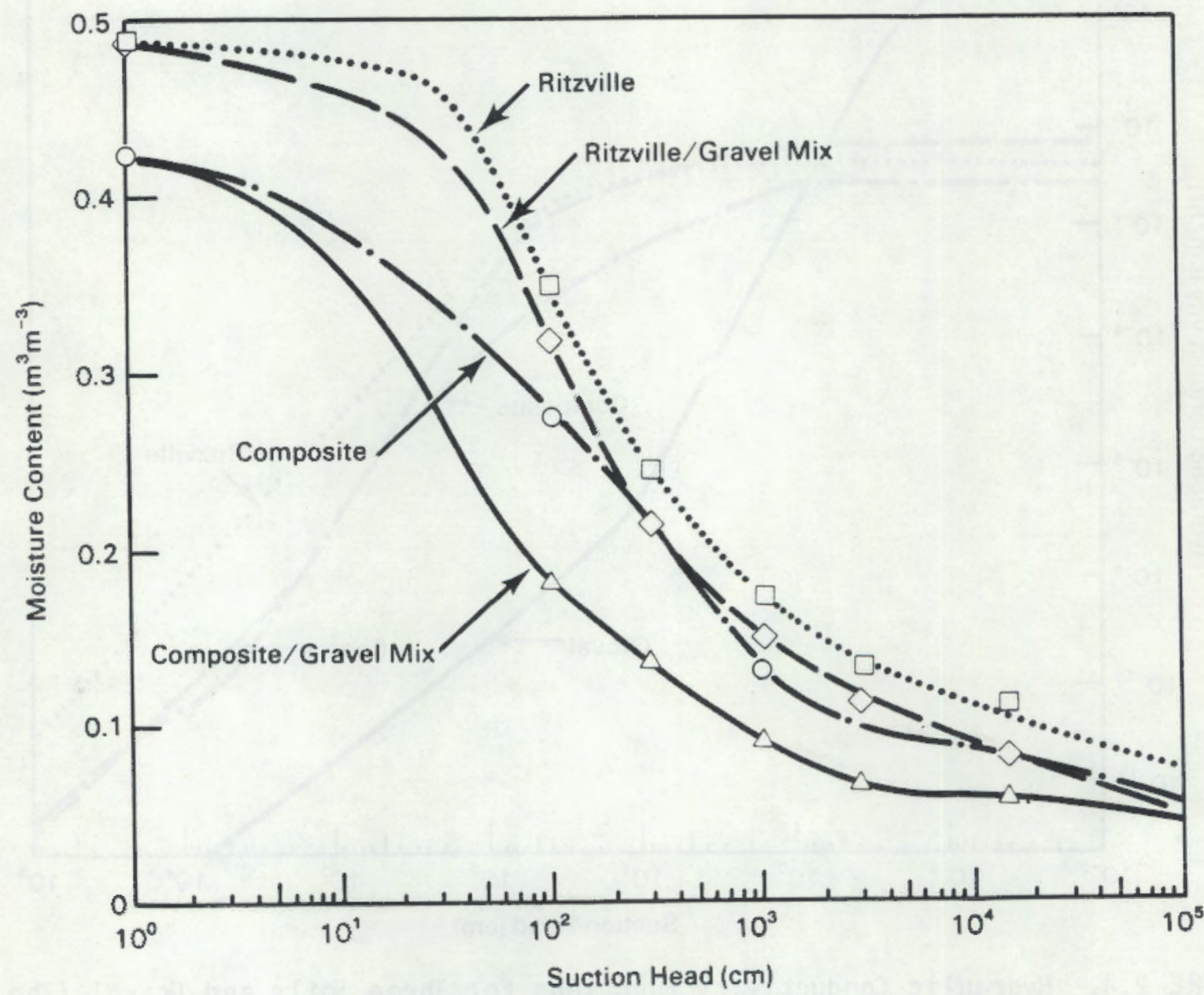

FIGURE 2.5. Moisture Characteristic Curves for Two Soils with and Without Gravel Added 


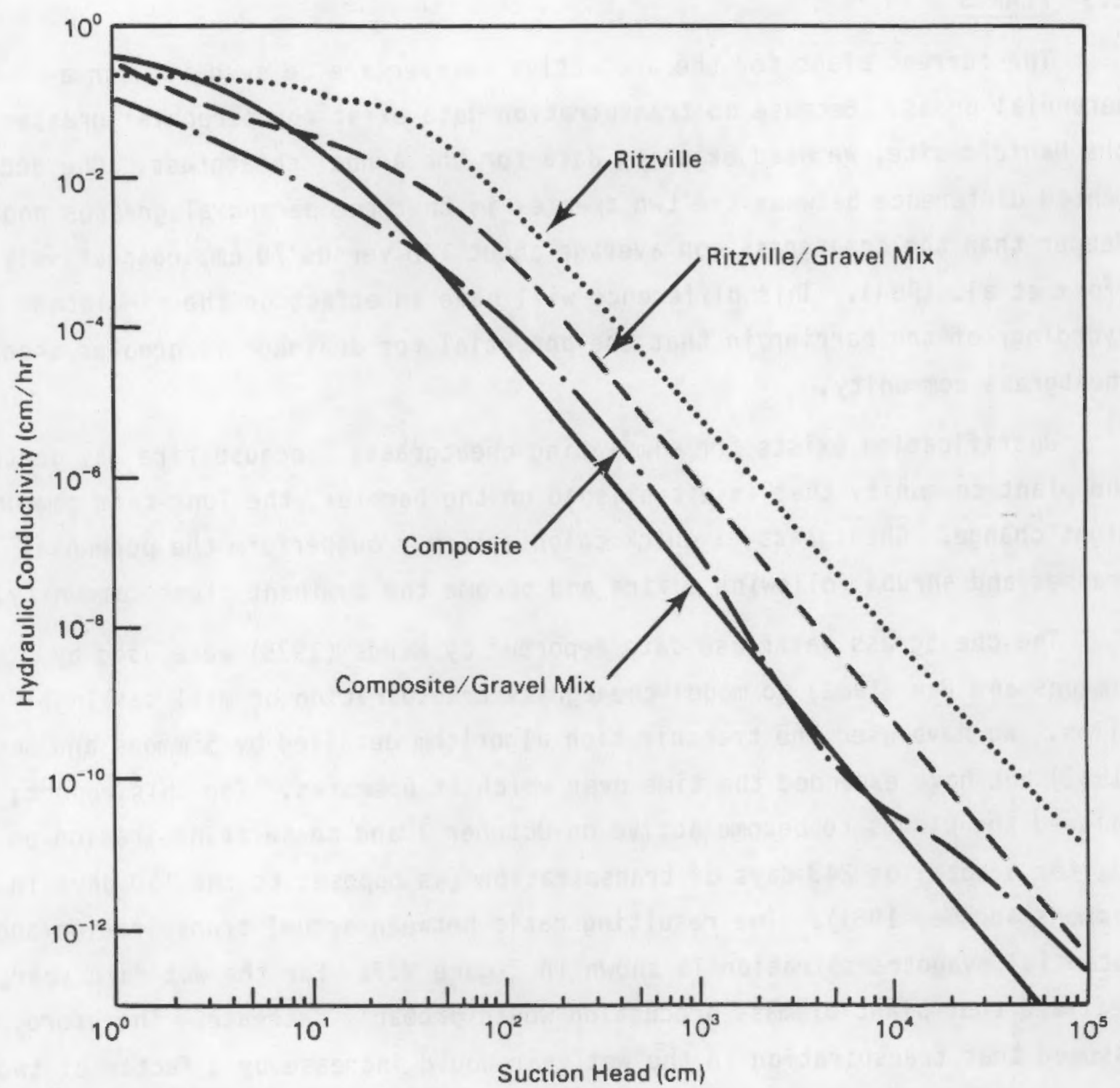

FIGURE 2.6. Hydraulic Conductivity Functions for Two Soils with and Without Gravel Added

as the pure soils. The effect of the gravel is to slightly raise the conductivity near the saturated end of the function and reduce it at greater values of suction head. 


\subsection{PLANTS}

The current plans for the protective barrier are to seed it with a perennial grass. Because no transpiration data exist for perennial grasses at the Hanford site, we used existing data for the annual cheatgrass. One documented difference between the two species is that the perennial grasses root deeper than the cheatgrass, on average about 148 versus $70 \mathrm{~cm}$, respectively (Foxx et a 1. 1984). This difference will have an effect on the simulated hydrology of the barrier in that the potential for drainage is greater under a cheatgrass community.

Justification exists for simulating cheatgrass. Because fire may destroy the plant community that is established on the barrier, the long-term community might change. Cheatgrass, a quick colonizer, may outperform the perennial grasses and shrubs following a fire and become the dominant plant community.

The cheatgrass water-use data reported by Hinds (1975) were used by Simmons and Gee (1981) to model cheatgrass transpiration on mill tailings piles. We have used the transpiration algorithm detailed by Simmons and Gee (1981) but have expanded the time over which it operates. For this report, we allowed the plants to become active on October 1 and cease transpiration on May 31, for a total of 243 days of transpiration (as opposed to the 150 days in Simmons and Gee 1981). The resulting ratio between actual transpiration and potential evapotranspiration is shown in Figure 2.7. For the wet rain year, we realized that plant biomass production would probably increase. Therefore, we assumed that transpiration in the wet year would increase by a factor of two.

Year-end cheatgrass root distribution data are available from $\mathrm{Cl}$ ine et al. (1977). A function describing that root data (Fayer and Gee 1985) was used in this report to characterize root distributions throughout the growing season. Maximum rooting depth versus time data that can be referenced are not available. Therefore, we have used the relationship reported in Simmons and Gee (1981), in which roots reach a maximum rooting depth of $80 \mathrm{~cm}$ on growth day 70 (Table 2.1). For the wet year, we assumed that the roots would grow deeper into the profile. For this report, the roots were allowed to reach a maximum rooting depth of $150 \mathrm{~cm}$ (the soil-gravel interface) on growth day 140 . 


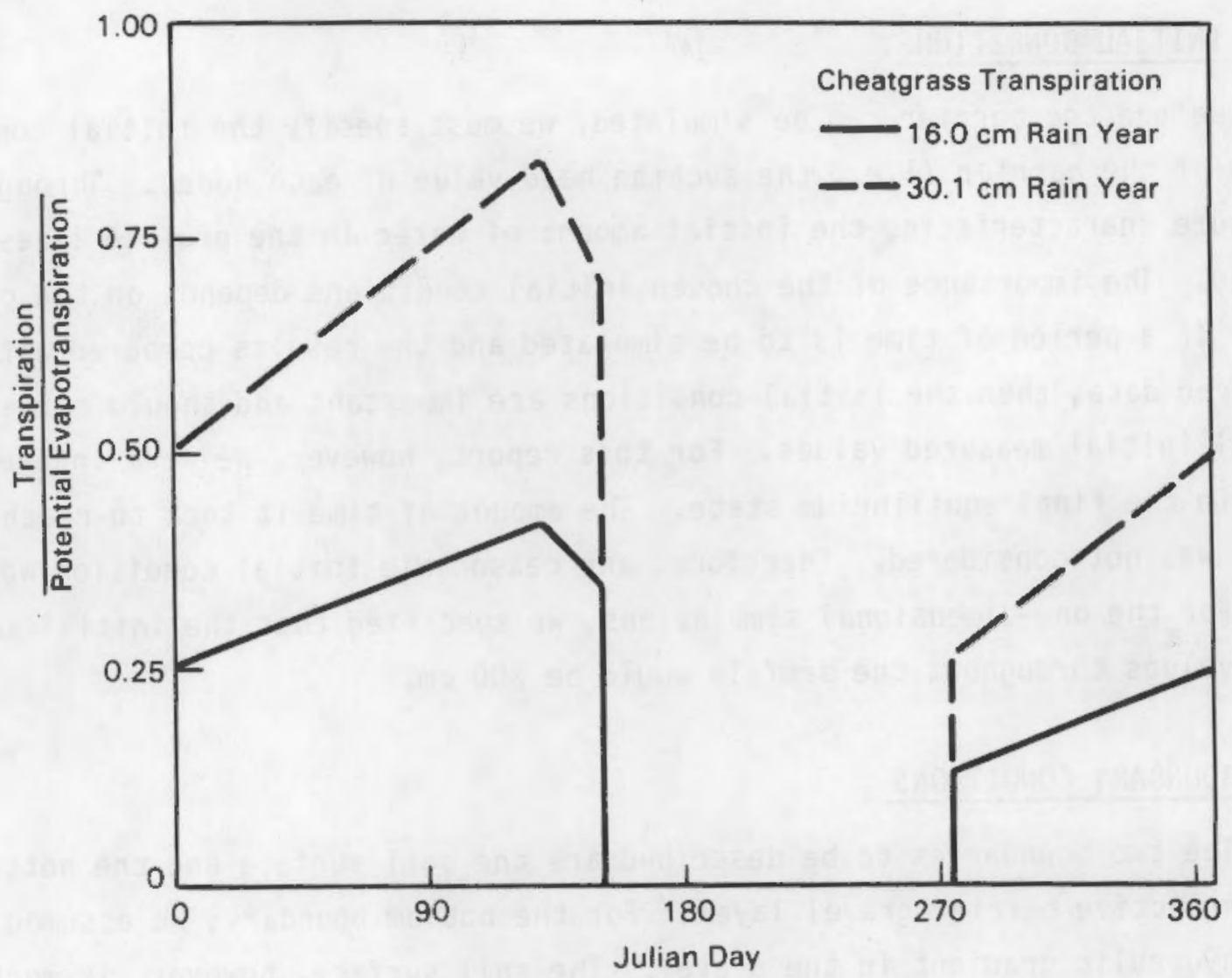

FIGURE 2.7. Cheatgrass Transpiration Function

TABLE 2.1. Maximum Rooting Depth During the Growing Season

\begin{tabular}{|c|c|c|}
\hline Soil Depth & Days Aft & Planting \\
\hline (cm) & & Wet Year \\
\hline 0.0 & 5 & 5 \\
\hline 2.5 & 6 & 6 \\
\hline 5.0 & 7 & 7 \\
\hline 7.5 & 8 & 8 \\
\hline 10.0 & 10 & 10 \\
\hline 15.0 & 11 & 11 \\
\hline 20.0 & 15 & 15 \\
\hline 25.0 & 16 & 16 \\
\hline 30.0 & 20 & 20 \\
\hline 35.0 & 25 & 25 \\
\hline 40.0 & 35 & 35 \\
\hline 50.0 & 40 & 40 \\
\hline 60.0 & 50 & 50 \\
\hline 70.0 & 60 & 60 \\
\hline 80.0 & 70 & 70 \\
\hline 100.0 & -- & 90 \\
\hline 150.0 & -- & 140 \\
\hline
\end{tabular}




\subsection{INITIAL CONDITIONS}

Before the barrier can be simulated, we must specify the initial conditions of the barrier (i.e., the suction head value of each node). Through the moisture characteristic, the initial amount of water in the profile is established. The importance of the chosen initial conditions depends on the problem. If a period of time is to be simulated and the results compared with measured data, then the initial conditions are important and should reflect the actual initial measured values. For this report, however, we were interested only in the final equilibrium state. The amount of time it took to reach that state was not considered. Therefore, any reasonable initial condition would do. For the one-dimensional simulations, we specified that the initial suction head values throughout the profile would be $200 \mathrm{~cm}$.

\subsection{BOUNDARY CONDITIONS}

The two boundaries to be described are the soil surface and the bottom of the protective barrier gravel layer. For the bottom boundary, we assumed a unit hydraulic gradient in the gravel. The soil surface, however, is much more complex because it includes the processes of precipitation and evaporation.

The distribution of precipitation through the year is an important factor affecting barrier performance (Gee and Simmons 1979). To simulate the longterm perfornance of a barrier at the Hanford site and preserve the historical precipitation pattern (Stone et al. 1983), we constructed an 'average rain year'. This year has the average yearly precipitation total for the Hanford site $(6.3 \mathrm{in})$ and the average yearly distribution (see Table 2.2). We took the average monthly precipitation for a particular month and found an earlier year in which that month's precipitation was similar; i.e., the average amount of precipitation for the month of January is $0.92 \mathrm{in}$. (snow is treated as an equivalent rainfall). We found that January 1968 had $0.88 \mathrm{in}$. recorded. Therefore, January 1968 became our representative January in our 'average rain year'. For simulations of the wet rain year $(30.1 \mathrm{~cm})$, we multiplied our 'average rain year' amounts by 1.883 . Other pertinent weather data, such as solar radiation, air temperature, and humidity are taken from the chosen representative months. 
IABLE 2.2. 'Average Rain Year' Constructed from the Hanford Weather Records

\begin{tabular}{|c|c|c|c|c|c|}
\hline \multirow[b]{3}{*}{ Month } & \multicolumn{5}{|c|}{ Monthly and Annual Precipitation } \\
\hline & \multicolumn{2}{|c|}{$\begin{array}{c}\text { Average } \\
1912 \text { to } 1980 \\
\end{array}$} & \multicolumn{3}{|c|}{$\begin{array}{l}\text { Average } \\
\text { Rain Year }\end{array}$} \\
\hline & in. & $\mathrm{cm}$ & in. & $\mathrm{cm}$ & Year \\
\hline January & 0.92 & 2.34 & 0.88 & 2.24 & 1968 \\
\hline February & 0.60 & 1.52 & 0.60 & 1.52 & 1981 \\
\hline March & 0.37 & 0.94 & $0.4 \pm$ & 1.04 & 1977 \\
\hline Apri 1 & 0.39 & 0.99 & 0.41 & 1.04 & 1976 \\
\hline May & 0.48 & 1.22 & 0.51 & 1.30 & 1969 \\
\hline June & 0.54 & 1.37 & 0.43 & 1.09 & 1981 \\
\hline July & 0.15 & 0.38 & 0.19 & 0.48 & 1981 \\
\hline August & 0.24 & 0.61 & 0.20 & 0.51 & 1982 \\
\hline September & 0.31 & 0.79 & 0.25 & 0.64 & 1968 \\
\hline October & 0.56 & 1.42 & 0.52 & 1.32 & 1983 \\
\hline No vember & 0.85 & 2.16 & 0.91 & 2.31 & 1982 \\
\hline December & 0.89 & 2.26 & 0.99 & 2.51 & 1979 \\
\hline Total & 6.30 & 16.00 & 6.30 & 16.00 & \\
\hline
\end{tabular}

When precipitation is not occurring, water can evaporate from the soil surface and, if plants are present, be transpired to the atmosphere from within the soil profile. Daily values of potential evapotranspiration, calculated using the Penman Equation according to 0oorenbos and Pruitt (1977), are input to the code. When there are no plants, the profile is allowed to evaporate the potential amount until the surface dries out to some maximum suction head. At that point, the surface head is held constant and the evaporation rate equals $\mathrm{s}$ what the soil can supply from below (Nimah and Hanks 1973). For all simulations, this maximum suction head was $10^{5} \mathrm{~cm}$.

When plants are present, the potential evapotranspiration is partitioned into evaporation and transpiration using the algorithm described in Section 2.3. If the soil is sufficiently dry, transpiration is reduced using a sink function of the type described by Feddes et al. (1978). Lacking sufficient data for cheatgrass, we assumed that water withdrawal from a given node will do one of the following: cease when the suction head is greater than 
$1.5 \times 10^{4} \mathrm{~cm}$, be reduced below the potential rate when the head is between $1.5 \times 10^{4}$ and $1.0 \times 10^{4} \mathrm{~cm}$, equal the potential rate when the head is between $1.0 \times 10^{4}$ and $5 \mathrm{~cm}$, or equal zero when the suction head is $<5 \mathrm{~cm}$ because conditions are assumed to be anaerobic. 


\subsection{RESULTS OF ONE-DIMENS IONAL SIMULATIONS}

The goal of the one-dimensional simulations was to find the final equilibrium drainage rates. When a specific barrier configuration resulted in an increase in overall storage from year to year, final equitibrium was defined as when overall storage remained constant from year to year and infiltration equalled drainage out the bottom of the barrier. When plants were on the barrier, however, the simulations were stopped before they reached an equilibrium state, because storage was decreasing and no drainage was occurring. Drainage results for the one-dimensional simulations are presented in Table 3.1 (see Appendix $B$ for a complete $l$ ist of results). The mass balance errors are all $<0.1 \mathrm{~cm}$.

The Composite soil simulations, most of the Composite/gravel mix simulations, and the Ritzville and Coarse simulations in the wet year with plants present, indicated the potential for runoff. Runoff occurs when the rainfall rate exceeds the infiltration capacity of the soil, sometimes called the soil infiltrability (Hillel 1980). Soil infiltrability is largely a function of the rainfall rate, the initial soil moisture content, the saturated hydraulic conductivity, and the presence of impeding layers. It is initially high, but over time infiltrability decreases toward a final steady-state value approximately equal to the saturated conductivity. Runoff should not occur unless the rainfall rate at least exceeds the saturated conductivity.

The maximum rainfall rate in the dry year was $7.1 \times 10^{-5} \mathrm{~cm} / \mathrm{s}$; in the wet year, it was $1.3 \times 10^{-4} \mathrm{~cm} / \mathrm{s}$. For the Composite soi 1 , the rainfall rate exceeded the saturated conductivity $\left(3.0 \times 10^{-5} \mathrm{~cm} / \mathrm{s}\right)$ during 8 events in the dry year and 33 events in the wet year. Therefore, runoff could occur from the Composite soil. For the Coarse soil, however, the rainfall rate never exceeds the soil's saturated conductivity of $1.5 \times 10^{-4} \mathrm{~cm} / \mathrm{s}$, yet there was a runoff potential of $0.2 \mathrm{~cm}$ in the wet year. This result indicates a deficiency in the ability of UNSAT-H to simulate runoff. Because runoff from certain barrier designs is a distinct possibility, UNSAT-H should be reviewed and changed to more accurately simulate the runoff process. 
TABLE 3.1. One-Dimensional Simulation Drainage Results. (Annual Drainage $<0.1 \mathrm{~cm}$ is reported as zero)

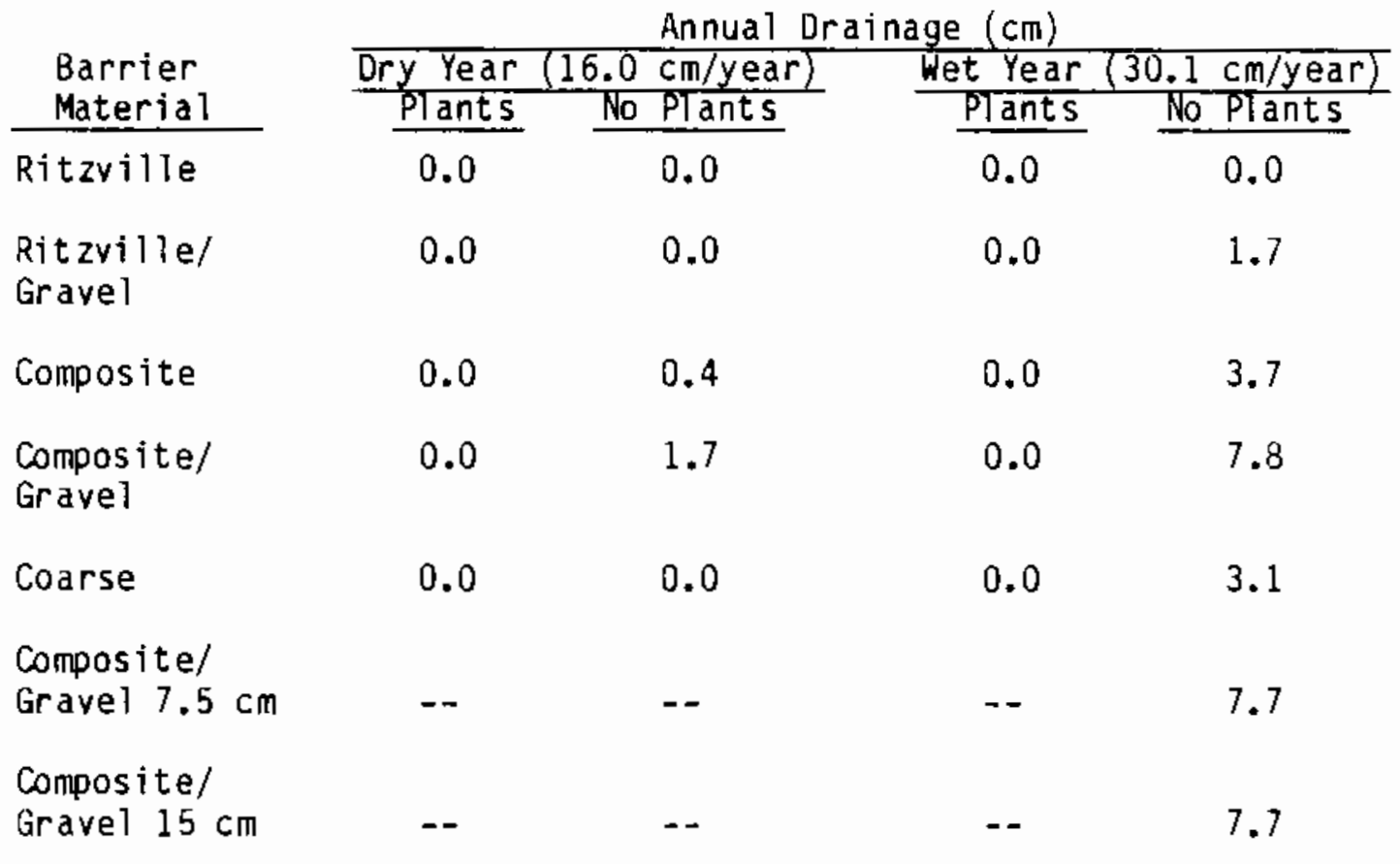

\subsection{SOIL TYPE}

For all soil types, drainage was zero (defined as $<0.1 \mathrm{~cm} / \mathrm{yr}$ ), provided plants were present on the barrier. A discussion follows for simulations with no plants.

Drainage differences among soil types were dramatic with no plants. The finest soil, the Ritzville, had no drainage in either the dry or wet year. It was able to transmit water readily from the lower layers to the evaporating surface. The Composite soil, on the other hand, drained in both the dry and wet years, 0.4 and $3.7 \mathrm{~cm}$, respectively. Because its unsaturated conductivity was lower than that of the Ritzville, it was much less successful in conducting water from the lower layers to the surface. This allowed some water to drain into the gravel underlayer.

The Coarse soil, which we expected would drain the most water because of its low water retention capacity, actually drained less than the composite (0 and $3.1 \mathrm{~cm}$ for the dry and wet years, respectively). In Appendix A, moisture retention data for the Composite and Coarse soils show that the Coarse 
sample holds less water in the suction head range of 300 to $1.53 \times 10^{4} \mathrm{~cm}$. Holding less water would be indicative of a coarse soil. In our simulations, however, suction head values in the 7 ower $50 \mathrm{~cm}$ of the soil layer varied from 0 to $100 \mathrm{~cm}$ throughout the year. There were no measured data in that range of suction. The curves in Figure 2.3 were drawn freehand between 0 and $100 \mathrm{~cm}$ of suction head. As a result, the coarse soil held more water than the composite in this range of suction head values. Therefore, the coarse soil's calculated unsaturated conductivity values were higher than those of the Composite. Higher unsaturated conductivities mean that the soil is better able to draw water from the deeper layers to the surface. As a result, the simulations indicated that the Coarse soil performs better that the Composite. This result shows that a need exists for a more accurate description of the moisture characteristic in the 0 - to $100-\mathrm{cm}$ range of suction head. It also indicates that the unsaturated conductivity function for the barrier soil is critical to the performance of the barrier in preventing drainage. Because of its importance, future work should include actual measurements of unsaturated conductivity. These measurements are currently being planned.

\subsection{GRAVEL MIX AODITION}

The addition of gravel to the top $30 \mathrm{~cm}$ of soil to prevent erosion had a pronounced effect on the hydrology of the barrier. For the Ritzville soil, the soil/gravel mix caused $1.7 \mathrm{~cm}$ of drainage compared to no drainage without it. For the Composite, the addition of the soil/gravel mix tripled drainage in the dry year, from 0.4 to $1.7 \mathrm{~cm}$, and doubled it in the wet year from 3.7 to 7.8 $c m$. Although the addition of gravel lowers the storage capacity of both soils, the main reason for its effect on drainage is that the gravel decreases the unsaturated hydrautic conductivity below that of the pure soil. For the Ritzville, the decrease occurs for suction head values above $1.2 \mathrm{~cm}$; for the Composite, the decrease occurs for suction head values above $45 \mathrm{~cm}$. Because of the lowered conductivity, the movement of water from the moist deeper layers to the evaporating surface is retarded. At and near the soil surface, head values often exceed $10^{3} \mathrm{~cm}$. At this head value, the conductivity of the Ritzville soil with and without gravel is $8.0 \times 10^{-7}$ and $6.0 \times 10^{-6} \mathrm{~cm} / \mathrm{hr}$, respectively, while the Composite is $4.0 \times 10^{-8}$ and $1.0 \times 10^{-7} \mathrm{~cm} / \mathrm{hr}$, respectively. Because 
the evaporation rate is largely dependent on the conductance of water from below (until vapor flow dominates), the gravel addition will serve to retard evaporation, thus allowing more water to be stored within the profile and avajlable for drainage.

\subsection{GRAVEL MIX THICKNESS}

In the previous section, we discussed the effects on drainage of incorporating gravel into the upper $30 \mathrm{~cm}$ of sojl. We can compare the results of four simulations in which the soil/gravel mix layer was $0,7.5,15$, and $30 \mathrm{~cm}$ thick. Only the wet year without plants was simulated. The simulated drainage amounts per year were $3.7,7.7,7.7$, and $7.8 \mathrm{~cm}$ for the respective thicknesses mentioned above. Overall, increasing the thickness of the gravel layer increased the amount of drainage. More importantly, however, was that most of the increase in drainage occurred when going from the pure soil to a soil/ gravel mix layer thickness of $7.5 \mathrm{~cm}$. Increasing the layer thickness further did not increase drainage proportionately. This finding indicates that the effect of the gravel on the soil surface and near-surface zone is most responsible for reducing evaporation and thus increasing drainage. Therefore, the decision to modify the surface with gravel is more important in determining the amount of drainage than is the thickness of the modified layer (at least for thicknesses of 7.5 to $30 \mathrm{~cm}$ ).

\subsection{DRY VERSUS WET YEARS}

As expected, increasing the rainfall from 16.0 to $30.1 \mathrm{~cm} / \mathrm{yr}$ increased the amount of drainage from some of the soils. Drainage from the Composite increased from 0.4 to $3.7 \mathrm{~cm} / \mathrm{yr}$. For the Coarse soil, drainage went from zero to $3.1 \mathrm{~cm} / \mathrm{yr}$. For the Ritzville soil, however, there was no drainage, even during the wet year. Clearly, fine-textured soils will perform better (limit drainage) than coarse-textured soils under increased rainfall conditions.

\subsection{PLANTS VERSUS NO PLANTS}

Of the variables tested for this report, plants had the largest effect on drainage. When plants were present, all of the barrier configurations had 
effectively no drainage during both the dry and wet years. These results are encouraging but tentative, because of the limited plant data (see section 2.3).

The plant root component of UNSAT-H is currently fixed; i.e., rooting depth versus time is the same every year regardless of whether the barrier becomes a swamp or dries out completely. Figure 3.1 is a plot of suction head values, initially and at the end of 2 and 5 years, for the Ritzville soil and the dry rain year. Note the extremely dry zone at the 30-cm depth at the end of 5 years. Once formed, that dry zone persisted year after year. Because rooting depths were fixed (see Table 2.1), plant transpiration removed water from below that dry zone. It is unlikely, however, that cheatgrass roots would readily penetrate such a dry layer. Until more data are available, we can only qualitatively predict that plants will decrease the amount of drainage.

\subsection{IMPERMEABLE LAYER}

For the case where the Composite soil had an 30 -cm-thick soil/gravel mix layer on the surface and no plants, an impermeable layer placed between the soil and gravel layers resulted in the formation of a water table on top of the impermeable layer. After repeated simulations, the water table was 80 and $124 \mathrm{~cm}$ on January 1 of the dry and wet years, respectively. The formation of a water table was expected because the barrier configuration used has already been shown to drain significant amounts of water. If that water is prevented from draining because of an impermeable layer, it will build up above the layer and form a water table. The accumulated water will remain there until it either evaporates, flows laterally to the barrier edge, or finds a defect in the impermeable layer through which it can flow downward. The presence of so much water, however, is likely to encourage plant growth, which could prevent the formation of a water table. 


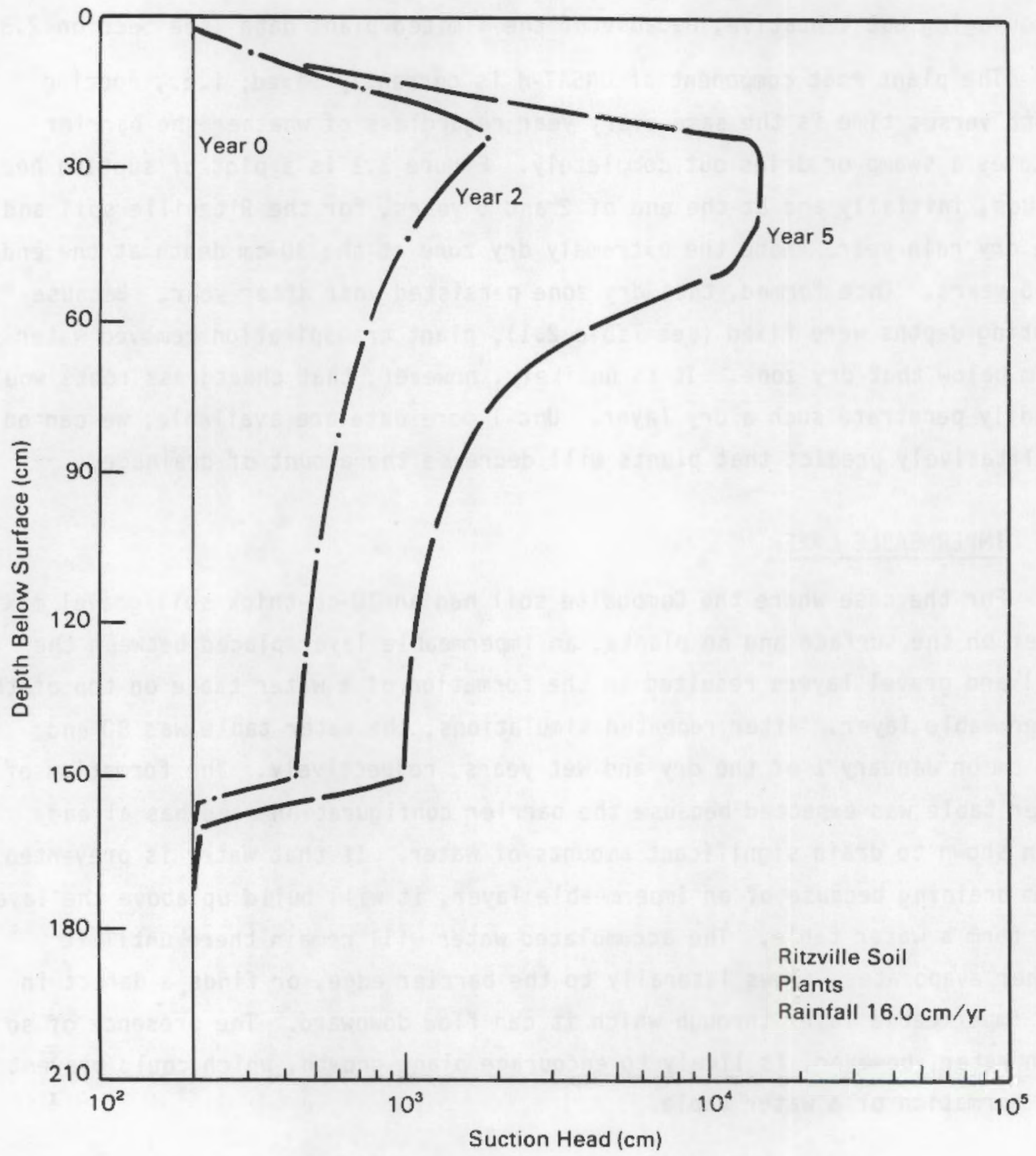

FIGURE 3.1. Year-End Suction Head Profiles for the Ritzville Soil and the Wet Rain Year 


\subsection{DESCRIPTION OF TWO-DIMENSIONAL SIMULATIONS}

Although the protective barrier could prove to be $100 \%$ effective at preventing drainage, we recognize that the potential exists for water from the surrounding soil to move under the barrier and contact the waste form. Further complicating the problem is the possibility that runoff may occur from the barrier. This runoff would likely infiltrate at the barrier edge and could move under the barrier and contact the waste form. Under these conditions, the potential for flowing water to reach the waste form depends, in part, on how far horizontally the waste is from the barrier edge. In this study, we simulated waste form locations of 10 and $20 \mathrm{~m}$ from the barrier edge. The goal of the study was to see what effect the waste location had on the potential for infiltrating water to contact the waste.

\subsection{BARRIER REPRESENTATION}

The dimensions of the barriers simulated here are 40 and $60 \mathrm{~m}$ wide with a $20-m$-wide waste form centered $10 \mathrm{~m}$ below the barrier. For the $60-\mathrm{m}$-wide barrier, called Case 1, the modeled area is shown in Figure 4.1. Perpendicular to the plane of Figure 4.1, the barrier and waste form dimensions are assumed to be infinite. With homogeneous material and equal infiltration on both sides, flow beneath the protective barrier is a symmetric problem with the axis of symmetry beneath the center of the barrier. Therefore, only half the barrier needs to be modeled. The bottom boundary at elevation $0 \mathrm{~m}$ is the water table, the top boundary at elevation $76 \mathrm{~m}$ is the soil surface, and the length of the modeled area is $60 \mathrm{~m}$ ( $30 \mathrm{~m}$ of soil plus $30 \mathrm{~m}$ of the barrier). The modeled area for Case 2 is identical, except that the modeled portion of the barrier is only $20 \mathrm{~m}$ long and the waste form is on 1 y $10 \mathrm{~m}$ from the barrier edge. A waste form located $65 \mathrm{~m}$ above the water table and $10 \mathrm{~m}$ from the right boundary is depicted in Figure 4.1. The waste form area is shown for reference only and does not indicate an alteration of the soil characteristics.

The problem was modeled with the transient, finite element code UNSAT2 (Neuman et al. 1974). The Composite soil, which is described in Section 2.2 


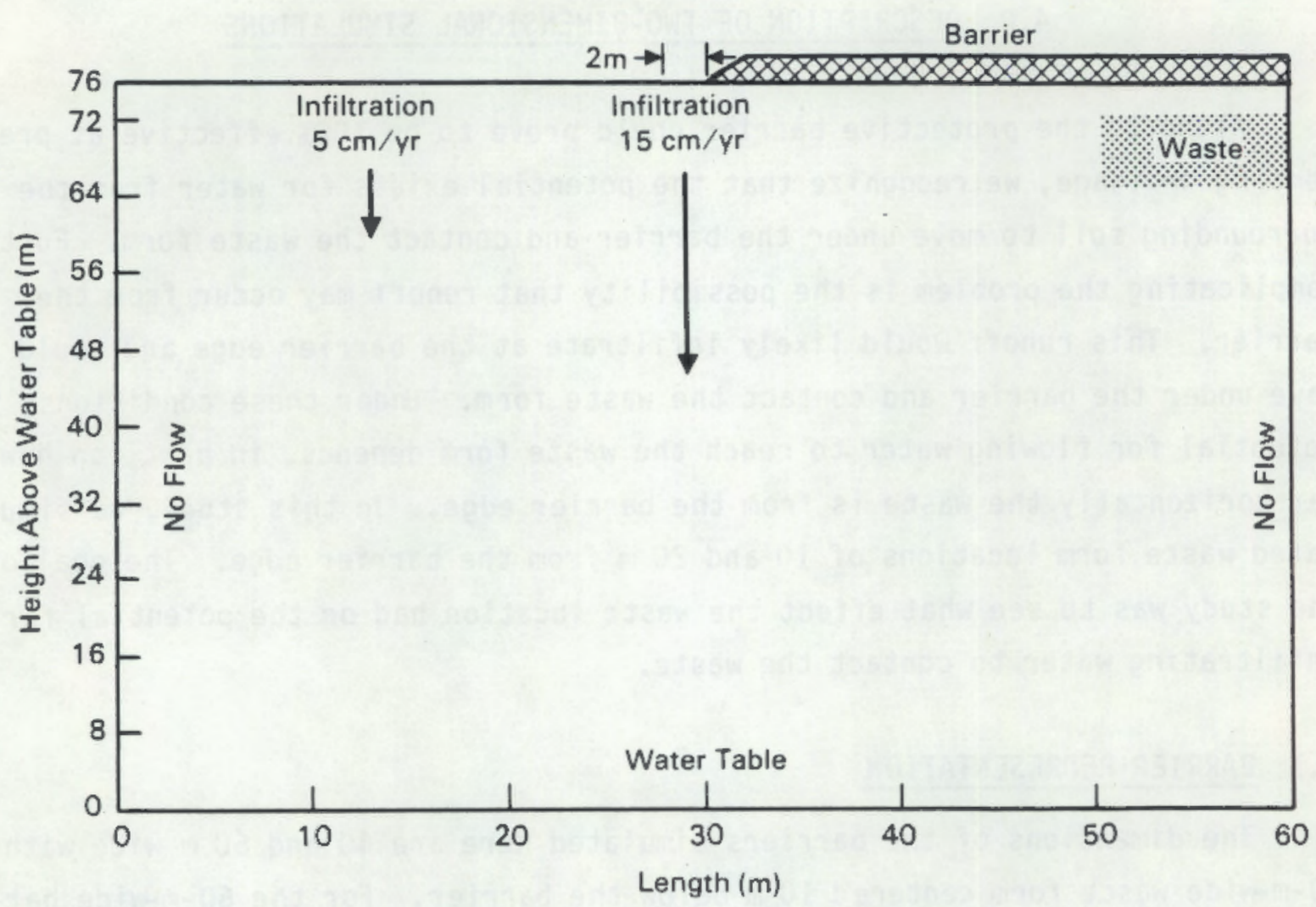

FIGURE 4.1. Two-Dimensional Representation of the Protective Barrier

and Appendix $A$, was used as the soil material, which was assumed to be homogeneous. The finite element grid is composed of triangular elements arranged in a symmetric pattern. The grid for Case 1 is shown in Figure 4.2. The finite element grid for Case 2 is identical except that $10 \mathrm{~m}$ (simulated by five columns of elements) on the right of the grid were removed. The grids are composed of triangular elements arranged in a symmetric pattern.

\subsection{INITIAL AND BOUNDARY CONDITIONS}

The initial conditions for both cases are such that the entire profile is in dynamic equilibrium with a steady net infiltration rate of $5 \mathrm{~cm} / \mathrm{yr}$; i.e., we assumed that no barrier existed and the recharge rate was spread evenly throughout the year. The left boundary (see Figure 4.1 ) is $30 \mathrm{~m}$ from the barrier. We assumed that the barrier would not affect flow at that distance 


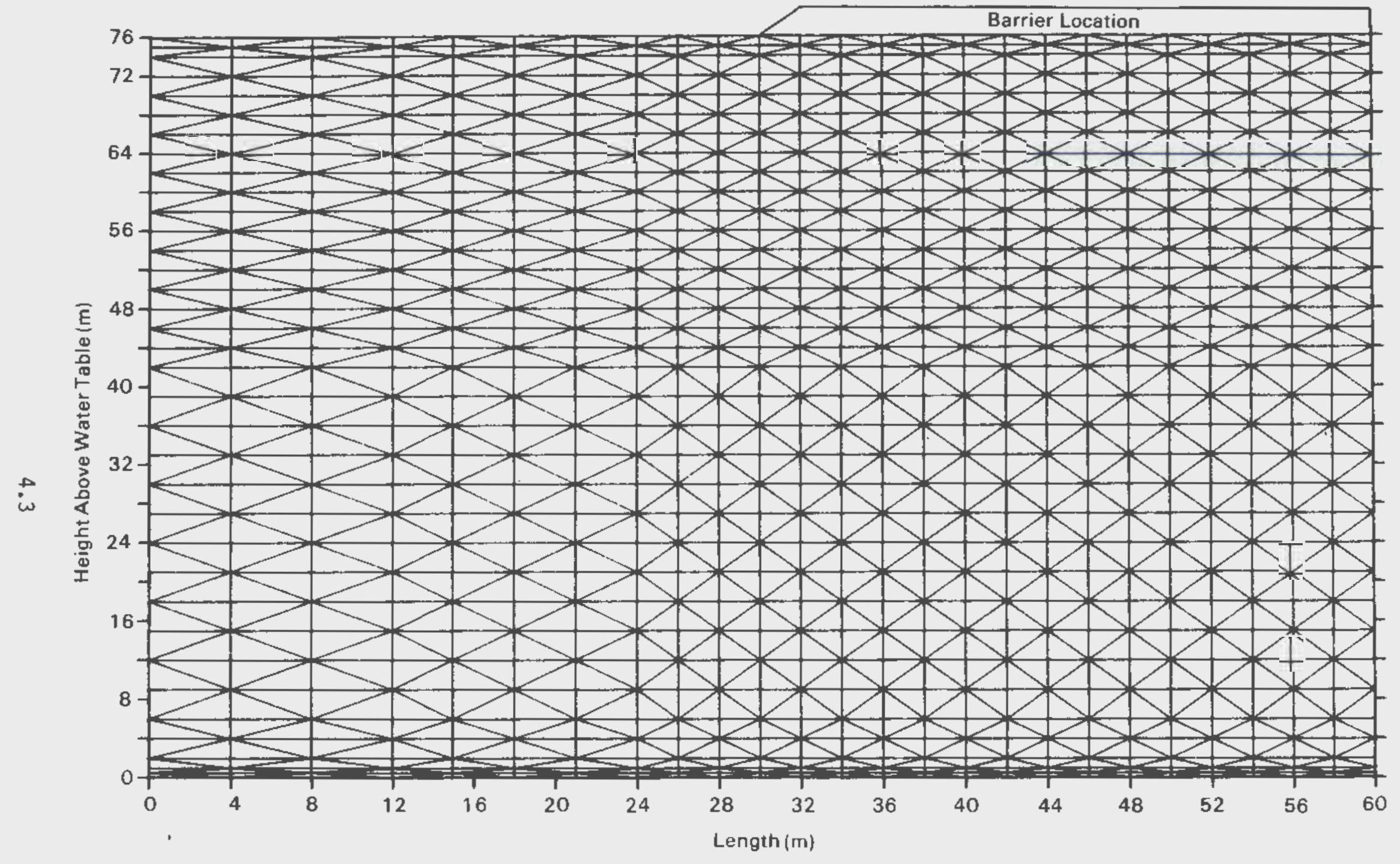

FIGURE 4.2. Finite Element Grid for the Two-Dimensional Simulations 
and that flow would remain essentially vertical. Thus, we assumed the left boundary to be a no-flow boundary. The right boundary, the axis of symmetry, is also a no-flow boundary. We held the bottom boundary constant as a water table condition.

At time zero, infiltration through portions of the upper boundary is changed to that indicated in Figure 4.1 ; i.e., infiltration through the barrier is zero, and infiltration through the $2-m$ area immediately to the left of the barrier increases to $15 \mathrm{~cm} / \mathrm{yr}$ to reflect runoff from the barrier. 


\subsection{RESULTS OF TWO-D IMENSIONAL SIMULATIONS}

Figures 5.1 and 5.2 show the contours of total head and volumetric moisture content, respectively, for Case 1 after 500 years. Figures 5.3 and 5.4 show similar contours for Case 2. In both cases, after 500 years, the total head profiles adjacent to the left boundary are identical to the initial conditions. This confirms our assumption of a no-flow left boundary located 30 $\mathrm{m}$ from the barrier edge.

In Case 1 (see Figure 5.1), the total head profile along the entire right boundary is horizontal. Near the waste form, in particular, the horizontal profile extends inward about $16 \mathrm{~m}$. This profile indicates that flow near the right boundary is vertical and that moisture from the infiltration boundary has not penetrated the region of the waste form after 500 years.

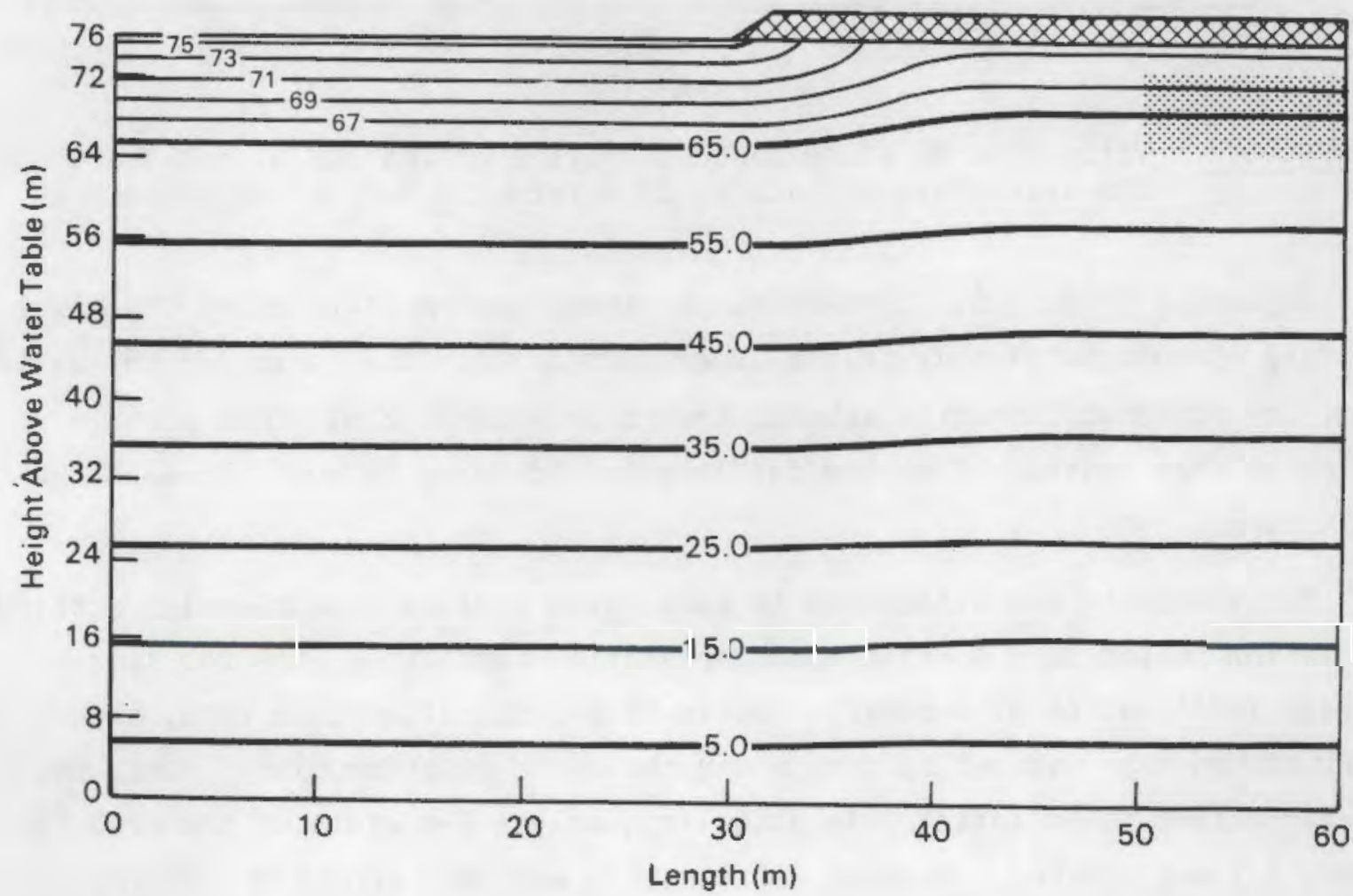

FIGURE 5.1. Total Head Profile at the End of 500 Years when the Waste Form is Located $20 \mathrm{~m}$ from the Barrier Edge (Case 1) 


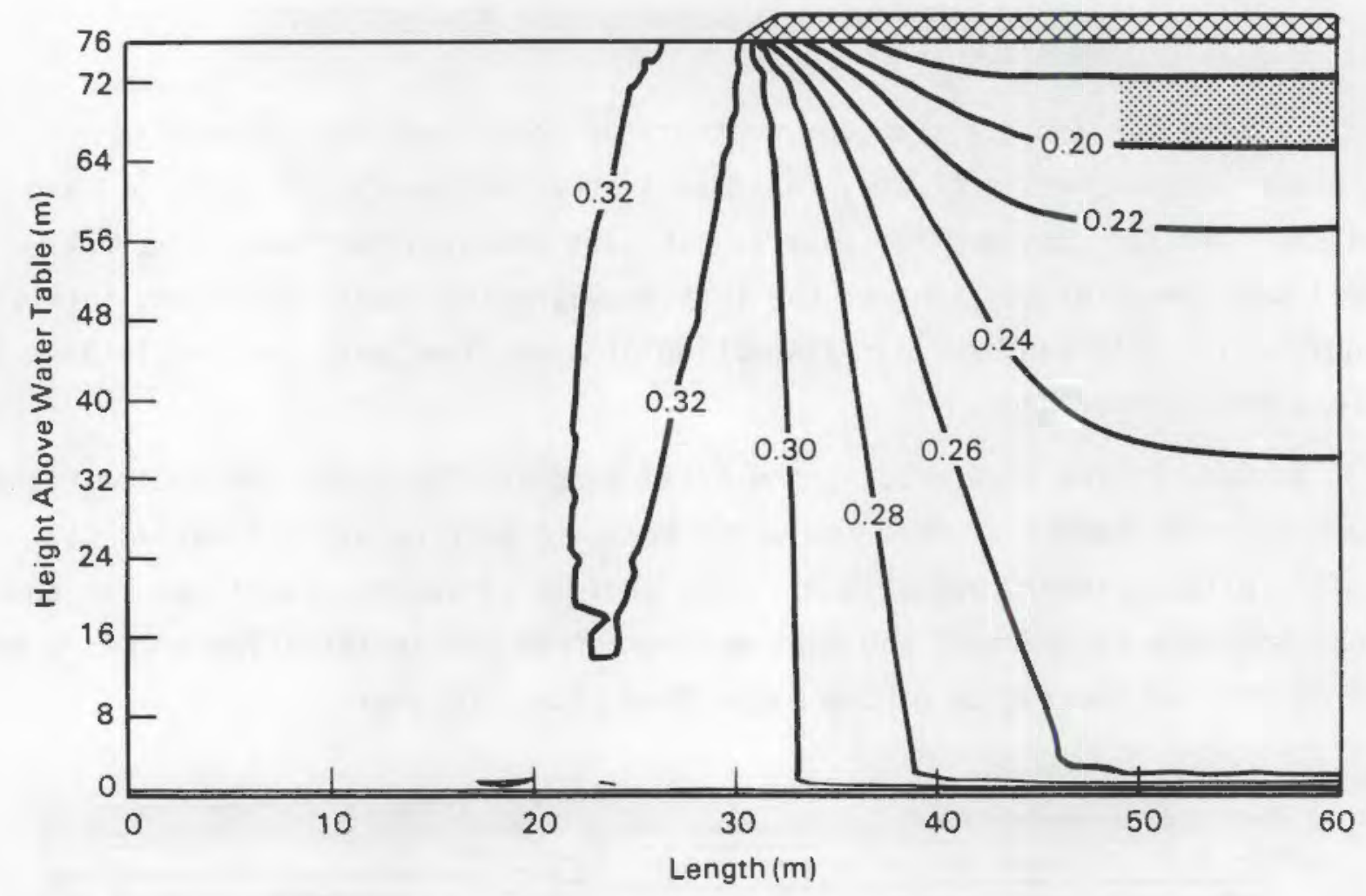

FIGURE 5.2. Volumetric Moisture Content Profile at the End of 500 Years when the Waste Form is Located $20 \mathrm{~m}$ from the Barrier Edge (Case 1)

In Case 2 (Figure 5.3), however, the total head profile along the right boundary is horizontal only in the upper portion. In the region of the waste form, the horizontal profile extends inward only about $3 \mathrm{~m}$. This profile indicates that moisture from the infiltration boundary is moving toward the waste form.

To illustrate the difference in total head profile more clearly, a third simulation called Case 0 was done. The initial conditions were the same (steady infiltration of $5 \mathrm{~cm} / \mathrm{yr}$ ), but in this case, after time zero, the infiltration rate was set to zero along the whole upper boundary (i.e., the barrier extent is infinite). In actuality, only a $6-m$ width of the area in Figure 4.1 was modeled. Because infiltration was zero across the entire surface, however, flow is one-dimensional and the results can be extrapolated to any width. 


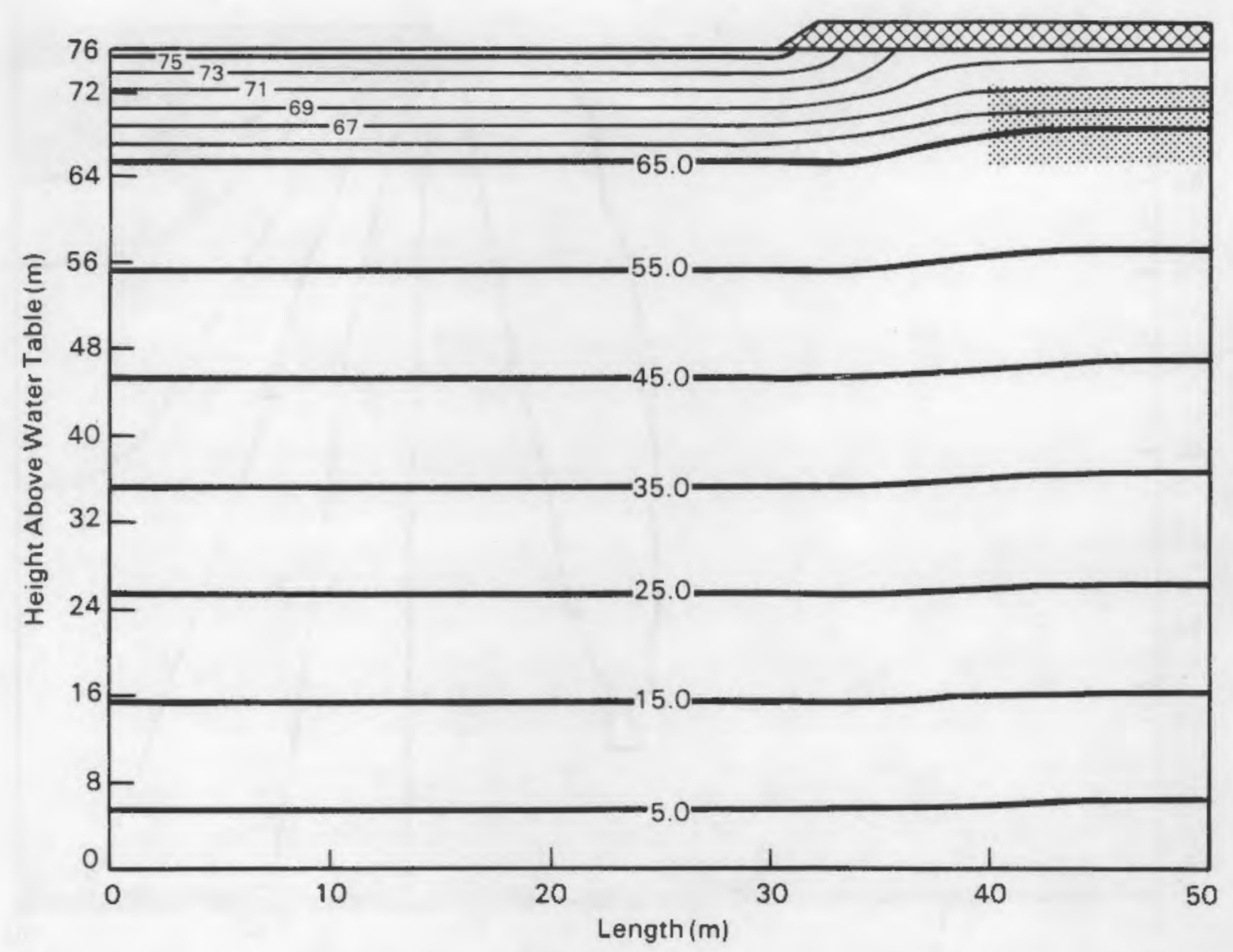

FIGURE 5.3. Total Head Profile at the End of 500 Years when the Waste Form is Located $10 \mathrm{~m}$ from the Barrier Edge (Case 2)

The results in Figure 5.5 are for the region in each case that contains the waste form. They show that for case 0 , the total potential contours are horizontal after 500 years. For Case 1 , in which the waste is $20 \mathrm{~m}$ from the barrier edge, the total head contours are identical to those of case 0 , the barrier of infinite extent. This finding indicates that flow in the waste region is still one-dimensional in the vertical direction. Therefore, water infiltrating at the barrier edge is not reaching the waste. For Case 2, however, the total head profiles are quite clearly different. These profiles indicate that there is flow from the barrier edge toward the waste form. Thus, the horizontal distance from the barrier edge has an effect on the long-term exposure of the waste form to flowing water. 


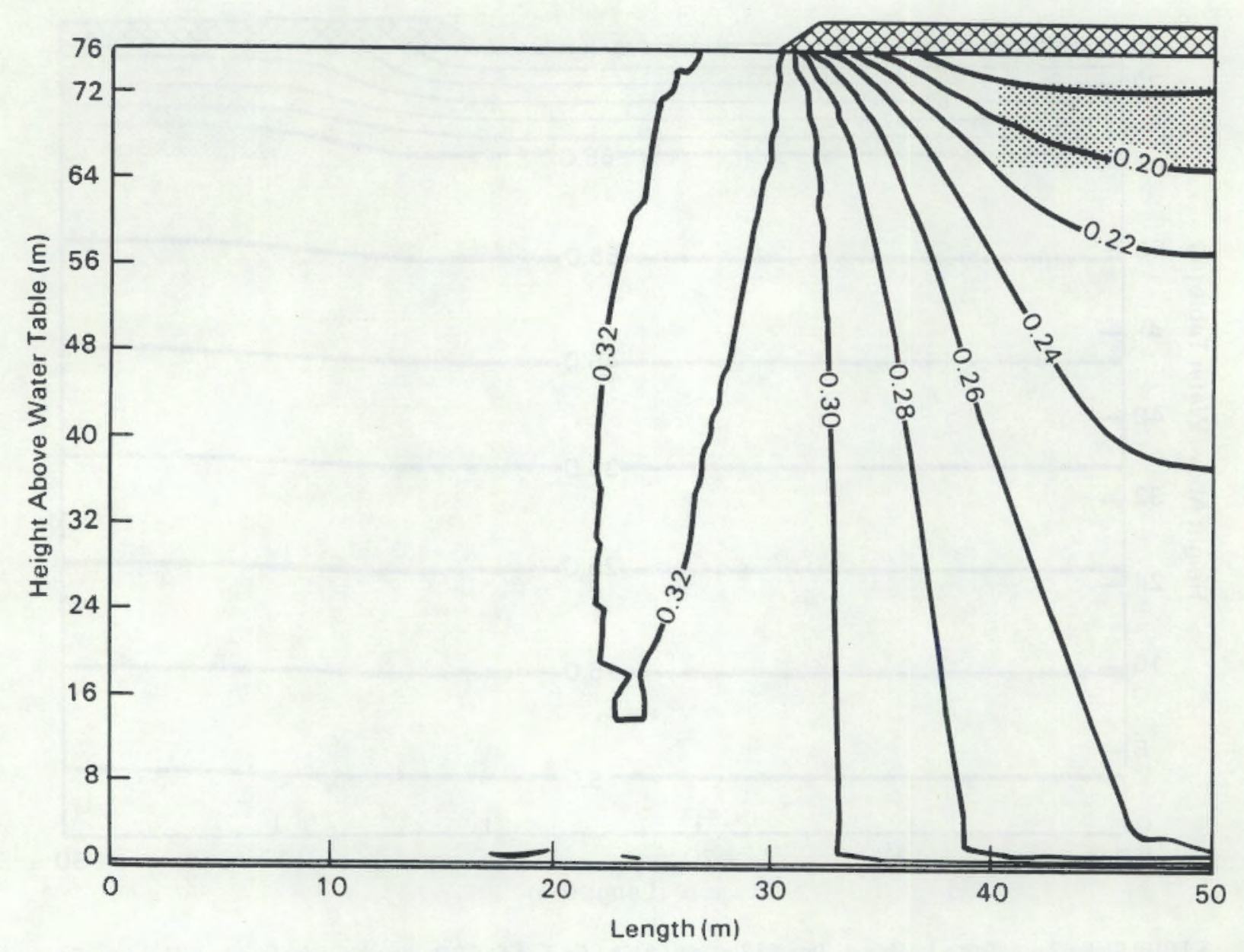

FIGURE 5.4. Volumetric Moisture Content Profile at the End of 500 Years when the Waste Form is Located $10 \mathrm{~m}$ from the Barrier Edge (Case 2)

This analysis does not indicate how much water might reach the waste form or what the travel time between the waste form and the water table might be. The soil used in this exercise, the composite, is finer in texture than most soils at the Hanford site. If, indeed, the soil surrounding the waste is coarser in texture than the Composite, then the results reported here should be viewed as conservative; that is, in a coarser soil, water infiltrating at the barrier edge would be less likely to move a significant distance under the barrier and contact the waste form. Additional cases that should be tested include simulations of long-term (1000 years) drainage using 1) coarser soil materials and 2) layered coarse and fine soils to simulate the effects of geologic layering of the surrounding soil on the lateral transport of water. 


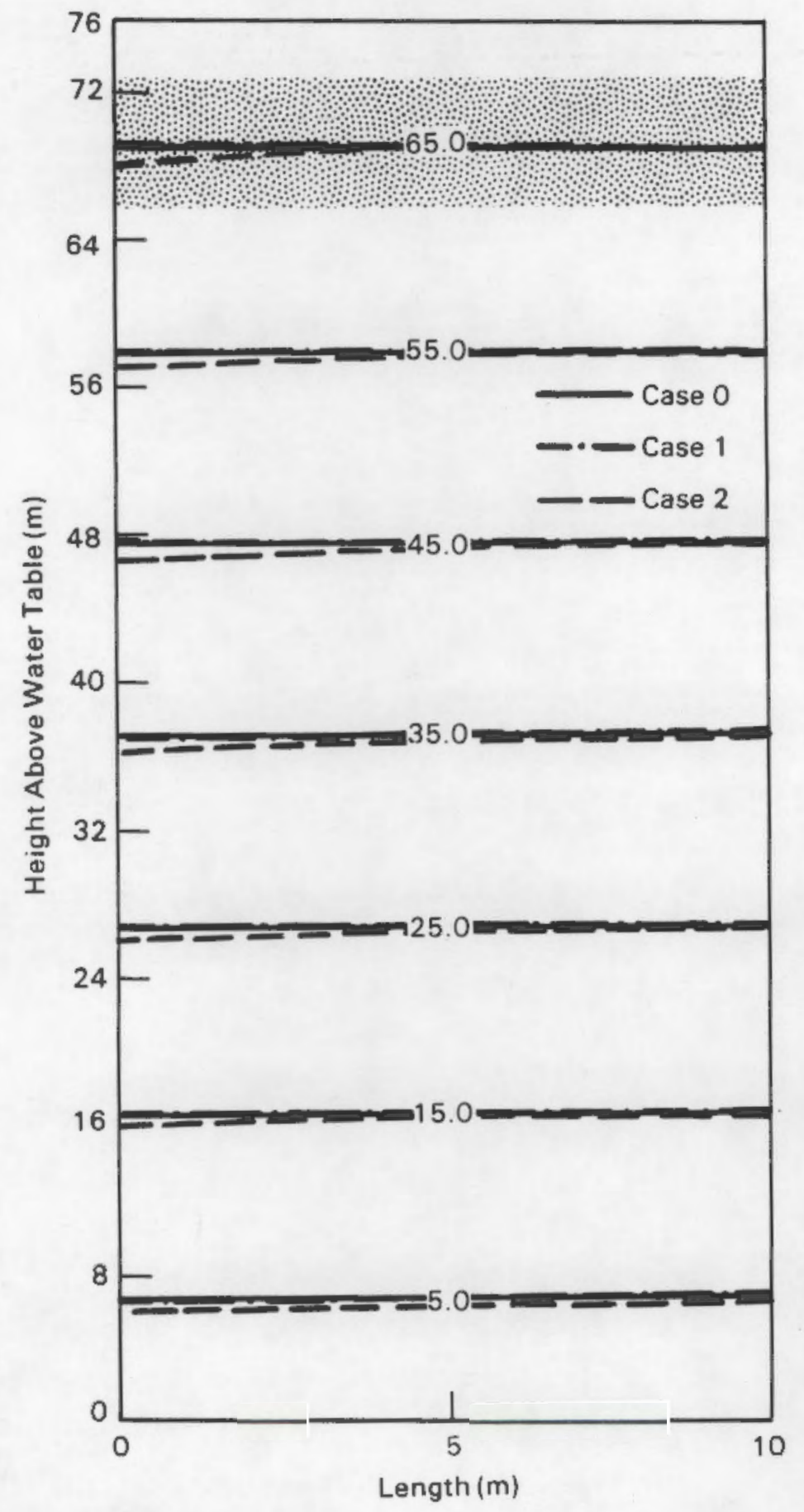

FIGURE 5.5. Total Head Profiles at the End of 500 Years in the Vicinity of the Waste Form 



\subsection{CONCLUSIONS AND RECOMMENDATIONS}

The simulation results presented in this report apply strictly to the conditions modeled. Extrapolation of these results to other situations is not suggested unless the reader has a clear understanding of the modeling process and the assumptions made in that process. However a number of conclusions can be drawn concerning barrier design to prevent drainage.

1. Soil Type: with plants present on the barrier, all three soils prevent drainage through the barrier. Without plants, only the Ritzville soil is able to recycle the precipitation sufficiently to prevent drainage. Although the Composite is a mix of samples that include the coarse soil, drainage through the Composite was greater than through the coarse soil. The differences in drainage are attributed to differences in the water retention characteristics and the estimated hydraulic conductivity functions. Even though the difference in hydraulic properties between the two soils is relatively small, it is sufficient for the Coarse soil to perform better (no drainage versus $0.4 \mathrm{~cm}$ in the dry year and 3.1 versus $3.7 \mathrm{~cm}$ in the wet year, respectively). This finding would suggest that hydraulic property characterization is critical to barrier performance and its correct simulation.

2. Soil/Gravel Mix Layer on the Surface: from a hydrologic standpoint, mixing gravel into the surface of the soil layer reduces the storage capacity of the soil and Iimits the overall ability of the nearsurface soil to transmit water to the evaporating surface. In the absence of a plant cover, reduced evaporation results in increased storage, thus rendering the barrier less effective at preventing drainage.

3. Thickness of the Surface Soil/Gravel Layer: changing the thickness from 30 to 15 to $7.5 \mathrm{~cm}$ did little to decrease the drainage rate below $7.8 \mathrm{~cm} / \mathrm{yr}$. This finding indicates that the properties of the top $7.5 \mathrm{~cm}$ (or less) of soil determine the evaporation rate. 
Therefore, the thickness of the surface soil-gravel layer is not as important as the fact that the surface has been modified.

4. Climate Change: with plants on the barrier, increased rainfall did not lead to drainage. Plant transpiration more than doubled in the wet year and thus offset the increased precipitation. The model was designed in this way and may not represent the actual plant response. Without plants on the barrier, increased rainfall leads to greater drainage through the barrier. If precipitation is increased sufficiently, any multilayer barrier will eventually fail.

5. Plant Change: loss of plant growth is critical. Drainage through the barrier only occurred when there were no plants on the barrier. one shortcoming of our plant simulations is that plant growth through the season is fixed. Thus, no opportunity exists for plants to respond to changing barrier conditions; i.e., when the barrier dried out, plant roots were still active throughout the profile wherever there was water. Whether the root growth rate of cheatgrass would be the same through desiccated layers as through wetter soil layers is questionable.

In cases where there were no plants, the barrier soil must be quite wet before significant drainage can occur. Therefore, for long-term (1000 years) modeling of barrier performance, plants should be considered to be an integral part of the barrier.

6. Distance from the Barrier Edge to the Waste Form: for the barrier design considered, moving the waste horizontally from 10 to $20 \mathrm{~m}$ from the barrier edge placed it outside the major zone of water flow from the surface area surrounding the barrier to the water table.

Based on the simulation results and the above-mentioned conclusions, we can make several recommendations for future work.

1. Material Property Characterization: as seen in the simulations of the Composite and Coarse soils, slight differences in the soil properties can make a significant difference in the drainage rate through the barrier. When characterizing soil for the barrier, more 
detailed measurements of the moisture characteristic in the 0 - to $100-c m$ range of suction head should be made. Particle-size analysis, although heipful in assessing the potential water storage capacity of a soil, will not be the ultimate test for determining which topsoil materials have suitable hydraulic properties. Measurements of water retention characteristics and in situ hydraulic conductivity functions will likely be the only way to ensure that suitable material has been selected for the barrier system.

Al though more-detailed measurement of the moisture characteristic will improve the estimation of the conductivity function, an effort should be made to actually measure the conductivity function. Such measurements would increase the dependability of the simulation results.

The rock properties used in this report were estimates. Any measurements of rock properties would put the simulation work on a firmer basis.

2. Fingering: although not addressed in this report, fingering (the phenomenon of unstable water flow when flow is from a fine-textured material down into a coarser material) may be a significant problem that the UNSAT-H model does not recognize. Through experimentation and simulation, the existence of fingering and its importance should be documented. This problem occurs when flow is nearly saturated, which will likely happen only when the barrier is about to drain.

3. Runoff: the simulation results indicate that runoff from a number of barrier designs is a distinct possibility. Because the UNSAT-M model does not adequately address runoff, however, we are uncertain as to the actual runoff potential. Therefore, an effort should be made to bolster the runoff algorithm of UNSAT-H.

4. Plants: plant growth responds to a changing environment and UNSAT-H should be upgraded to simulate this behavior. Experiments will be required that provide at least a rudimentary data base for estimating plant growth responses and for verifying the model. 
5. Climate: the use of an average rain year in this report has limited value for long-term predictions. More effort should be expended in representing the future Hanford site climate with some type of stochastic mode1.

6. Soil Surrounding the Waste Form: the in situ soil that will be surrounding the waste form under the barrier should be characterized hydrologically. The two-dimensional analysis performed for this report should be repeated using the in situ soil properties to see if the waste has to be located $20 \mathrm{~m}$ from the barrier edge. In addition, the total head profile in the vicinity of the waste form should be better defined, streamilines should be plotted, and travel times calculated. 


\subsection{REFERENCES}

Bond, F. W., C. R. Cole and P. J. Gutknecht. 1984. Unsaturated Groundwater Flow Model (UNSAT1D) Computer Code Manual. CS-2434-CCM, Electríc Power Research Institute, Palo Alto, California.

Cline, J. F., D. W. Uresk and W. H. Rickard. 1977. "Comparison of Soil Water Used by a Sagebrush-Bunchgrass and a Cheatgrass Community." J. Range Manage. 30:199-201.

Doorenbos, J., and W. O. Pruitt. 1977. "Guidelines for Predicting Crop Water Requirements," FAO Irrigation Paper No. 24, 2nd ed., Food and Agricultural Organization of the United Nations, Rome, Italy.

Fayer, M. J., and G. W. Gee. 1985. UNSAT-H, An Unsaturated So il Water Flow Code for Use at the Hanford Site: Code Documentation. PNL-5585, Pacifje Northwest Laboratory, Richland, Washington.

Feddes, R. A., P. J. Kowalik and H. Zaradny. 1978. Simulation of Field Water Use and Crop Yield. John Wiley and Sons, Inc., Kow York.

Foxx, T. S., G. D. Tierney and J. M. Williams. 1984. Rooting Depths of Plants on Low-Level Waste Disposal Sites. LA-10253-MS, Los Alamos National Laboratory, Los Alamos, Nexico.

Gee, G. W., and P. R. Heller. 1985. Unsaturated Water Flow at the Hanford Site: A Review of Literature and Annotated Bibliography. PNL-5428, Paciffic ibrthwest Laboratory, Richtand, Washington.

Gee, G. W., and C. S. Simmons, 1979. Characterization of the Hanford 300 Area Burial Grounds. Task III - Fluid Transport and Modeling. PNL-2921, Pacific Northwest Laboratory, Richland, Washington.

Mill, D. E., and J. Y. Parlange. 1972. "Wetting Front Instability in Layered Soils." Soil Sci. Soc. Amer. Prac. 36(5):697-702.

Hillel, D. 1980. Applications of Soil Physics. Academic Press, Inc., New York.

Hinds, W. T. 1975. "Energy and Carbon Balances in Cheatgrass: An Essay in Autecology." Ecological Monographs 45:367-388.

Miller, D.E., and W. C. Bunger. 1963. "Moisture Retention by Soil with Coarse Layers in the Profile." Soil. Sci. Soc. Amer. Proc. 27(5):586-589.

Millington, R. J., and J. P. Quirk. 1961. "Transport in Porous Media." Trans. Faraday Soc. 57:1200-1207. 
Neuman, S. P., R. A. Feddes and E. Bresler. 1974. Finite Element Simulation of Flow in Saturated-Unsaturated Soils Considering Water uptake By Plants. In Development of Methods, Tools and Solutions for Unsaturated Flow, Third Annual Report, (Part 1). Technion, Is rael Institute of Technology, Haifa.

Nimah, M. N., and R. J. Hanks. 1973. "Model for Estimating Soil Hater, Plant, and Atmospheric Interrelations: I. Description and Sensitivity." Soil Sci. Soc. Amer. Proc. 37:522-527.

Simmons, C. S., and G. W. Gee. 1981. Simulation of Water Flow and Retention in Earthen Cover Materials Overlying Uranium Mill Tailings. PNL-3877, Pacific Northwest Laboratory, Richland, Washington.

Stone, W. A., J. M. Thorp, D. P. Gifford and D. J. Hoitink. 1983. Climatological Summary for the Hanford Area. PNL-4622, Pacific Northwest Laboratory, Richland, Washington.

Unger, P. W. 1971. "Soil Profile Gravel Layers: I. Effect on Water Storage, Distribution, and Evaporation." Soil Sci. Soc. Amer. Proc. 35:631-634. 
APPENDIX A

MATER IAL PROPERTIES 


\section{MATERIAL PROPERTIES}

\section{A.1 MATERIAL SELECTION}

Thirty-three samples were evaluated for particle size, water retention characteristics (at 102-,306-, 1,020-, 3,060-, and 15,300 suction head), and water storage. From these data, the 'best' soil for the surface of the protective barrier was chosen for further study. The samples studied were as follows:

$$
\begin{aligned}
& \text { 1. GMP } 1 \text { 18. } 43-88,0 \text { to } 10 \mathrm{ft} \\
& \text { 2. GMP } 2 \text { 19. 43-88, No. } 1 \\
& \text { 3. GMP } 3 \text { 20. 43-88, No. } 2 \\
& \text { 4. GMP } 4 \text { 21. 43-88, №. } 3 \\
& \text { 5. GMP } 5 \text { 22. } 43-88 \text {, No. } 4 \\
& \text { 6. GMP } 6 \text { 23. } 43-88 \text {, No. } 5 \\
& \begin{array}{ll}
\text { 7. } 34-88,0 \text { to } 10 \mathrm{ft} \text { 24. } 43-88 \text {, No. } 6
\end{array} \\
& \text { 8. 36-89, 0 to } 10 \mathrm{ft} \text { 25. 43-88, No.7 } \\
& \text { 9. } 36-89,10 \text { to } 20 \mathrm{ft} \text { 26. 43-88, No. } 8 \\
& \text { 10. 37-88, } 0 \text { to } 20 \mathrm{ft} \text {. Cold Creek Valley } \\
& \text { 11. 37-89, } 0 \text { to } 5 \mathrm{ft} \text { 28. Fly Ash } \\
& \text { 12. } 37-89,5 \text { to } 10 \mathrm{ft} \text { 29. Composite } w / \text { grave? } \\
& \text { 13. 38-88, } 0 \text { to } 5 \mathrm{ft} \text { 30. Composite w/o gravel } \\
& \text { 14. 38-88, } 5 \text { to } 10 \mathrm{ft} \text { 31. Ritzville w/ gravel } \\
& \text { 15. 42-88, } 0 \text { t0 } 10 \mathrm{ft} \text { 32. Ritzville w/o gravel } \\
& \text { 16. 45-68, } 0 \text { to } 5 \mathrm{ft} \text { 33. Coarse }(43-88 \text { No.6, bulk } \\
& \text { 17. 47-60,0 to } 5 \mathrm{ft} \text { density }=1.6 \mathrm{~g} / \mathrm{cm}^{3} \text { ) }
\end{aligned}
$$

GMP refers to the Gable Mountain Pond. The numbers, such as 34-88, refer to wells that are adjacent to the sampling point. The sampling locations are on the Hanford site as shown in Figure A.1. When preliminary analyses indicated that soil near we11 43-88 might be suitable for the barrier, eight 


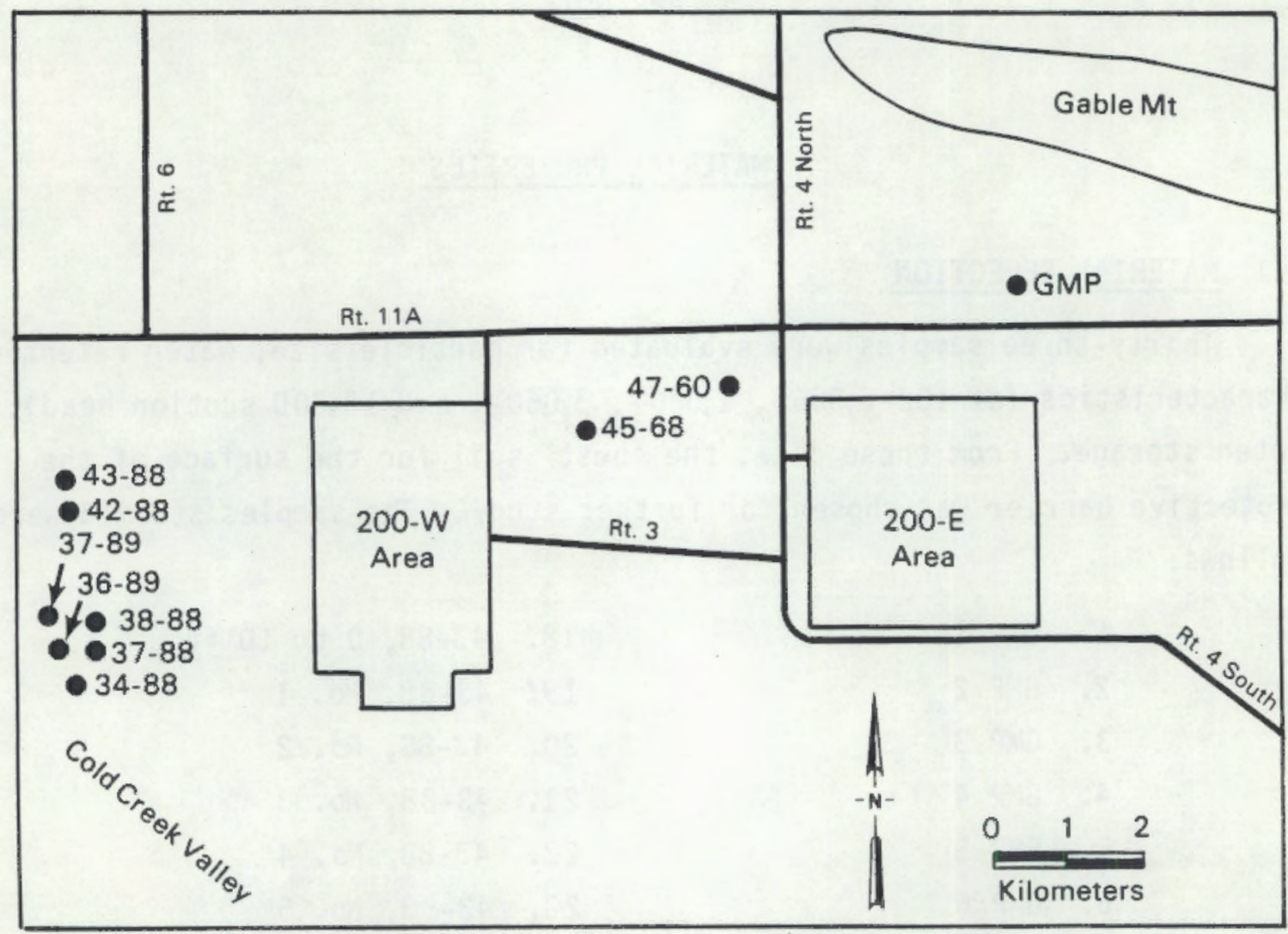

FIGURE A.1. Map of the 200-Area Sampling Sites (GMP refers to Gable Mountain Pond. Numbers such as 43-88 refer to wells that are adjacent to the sampling point.)

additional samples were taken in that vicinity to gauge the quantity of soil available. The additional samples are listed as 43-88, Nos. 1 through 8.

If the soil near well 43-88 is approved as barrier material, then the variability in samples 1 through 8 might become important. We created a single soil (the Composite) by mixing the separate soils into one. The Composite was used in the model simulations described in this report. A separate material was also created in which gravel (15 wt\%) was mixed with the Composite. Such a material may be used on the surface of the soil layer to protect against erosion.

The second soil used in the simulations was the Ritzville silt loam, which is found on the Arid Lands Ecology Reserve of the Hanford site (near Rattlesnake Mountain to the west). This material provides a fine-textured soil 
against which we can contrast the Composite soil. Just as we did for the Composite, we created a separate material by mixing gravel (15 wt\%) with the Ritzville.

The final soil used in the simulations was sample No. 6 from the vicinity of wel 1 43-88. When packed to a bulk density of $1.6 \mathrm{~g} / \mathrm{cm}^{3}$, this sample, which we have called Coarse, retained the least amount of water compared with the other samples from weli 43-88.

\section{A.2 MATERIAL CHARACTERIZATION}

\section{A.2.1 Water Retention}

Equilibrium water contents $(\theta)$ were obtained by packing samples in containing rings on a porous ceramic plate where they were saturated and pressure-drained. (a) Water contents were measured at pressure heads of 102 , $306,1,020,3,060$, and $15,300 \mathrm{~cm}$ of water using a pressure plate extractor.

Both the samples and porous plate were brought to saturation by allowing an excess of water to stand on the surface of the plate for $24 \mathrm{~h}$. On complete saturation, the plate was placed in the extractor vessel and the internal air pressure raised to the desired test level. Equilibrium was reached when drainage ceased. At the end of the run, the samples were weighed and oven-dried to determine the moisture contents. Water-content data are tabulated in Table A.1 in terms of the associated suction head expressed in centimeters of water. At equilibrium, the applied pressure is equal to the suction head (Richards 1965).

\section{A.2.2 Saturated Hydraulic Conductivity}

The saturated hydrautic conductivity of nine materials (Table A.2) was determined using a constant head method (Klute 1965). Each sample was placed in a container $(5.4 \mathrm{~cm}$ dia, $3 \mathrm{~cm}$ high) and enclosed with lids having an inflow valve at one end and an outflow valve at the other end. The inflow valve was connected to a constant head device; the outflow valve was connected to a collection vesse1. Each sample was saturated before starting the test. After

(a) Product of Soilmoisture Equipment Corporation, Santa Barbara, CA 93105. 
TABLE A.l. Water Retention Data for Hanford Soil Samples

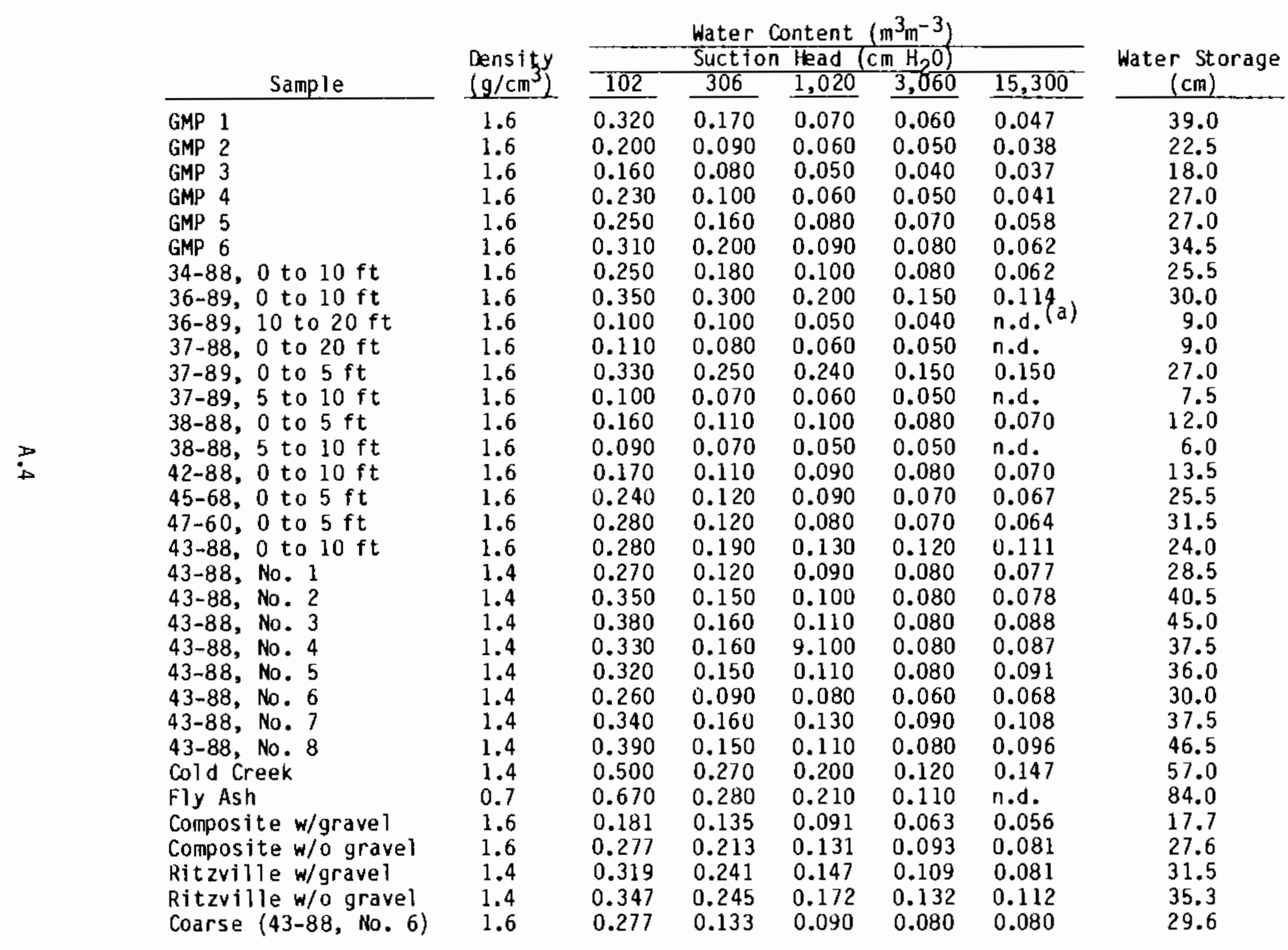

(a) n.d. = not determined 
TABLE A.2. Hydraulic Conductivity for Hanford Soil Samples

\begin{tabular}{|c|c|}
\hline Sample & Conductivity $(\mathrm{cm} / \mathrm{s})$ \\
\hline GMP $1(0$ to $5 \mathrm{ft})$ & $2.40 \times 10^{-4}$ \\
\hline $36-89(0$ to $10 \mathrm{ft})$ & $4.98 \times 10^{-5}$ \\
\hline $37-89(0$ to $5 \mathrm{ft})$ & $2.52 \times 10^{-5}$ \\
\hline $43-88(0$ to $10 \mathrm{ft})$ & $1.32 \times 10^{-4}$ \\
\hline Composite & $2.50 \times 10^{-5}$ \\
\hline Composite w/gravel & $1.24 \times 10^{-4}$ \\
\hline Ritzvilie & $6.52 \times 10^{-5}$ \\
\hline Ritzville w/gravel & $8.53 \times 10^{-5}$ \\
\hline Coarse $(43-88 \# 6)$ & $1.48 \times 10^{-4}$ \\
\hline
\end{tabular}

recording the initial time, water was allowed to flow through the sample for a predesignated amount of time and the amount of discharge recorded. The hydraulic conductivity was determined using the following equation:

$$
K=\frac{L}{\Delta H} \frac{Q}{A t}
$$

where $k=$ hydraulic conductivity, $\mathrm{cm} / \mathrm{s}$

$L=$ length of the sample, $c m$

$\Delta H=$ hydraulic head difference, $c m$

$Q=$ volume of water that passes through the sample in known time ' $t$ '

$A=$ cross-sectional area of the sample, $\mathrm{cm}^{2}$

$t=t$ ime, $s$

\section{A.2.3 Particle Size}

Particle size (Table A.3) was determined on two separate bases. Dry sieve analysis was done using sieve sizes of $2.0 \mathrm{~mm}$ and $63 \mu \mathrm{m}$ (No. 10 and 230 mesh Tyler numbers). Size distribution was done in accordance with ASTM procedure D 422 (ASTM 1985). For all samples, the sand, silt, and clay distribution was determined using only the <2 mm-sized particles from each large sample. The 
TABLE A.3. Particle Size for Hanford Soil Samples

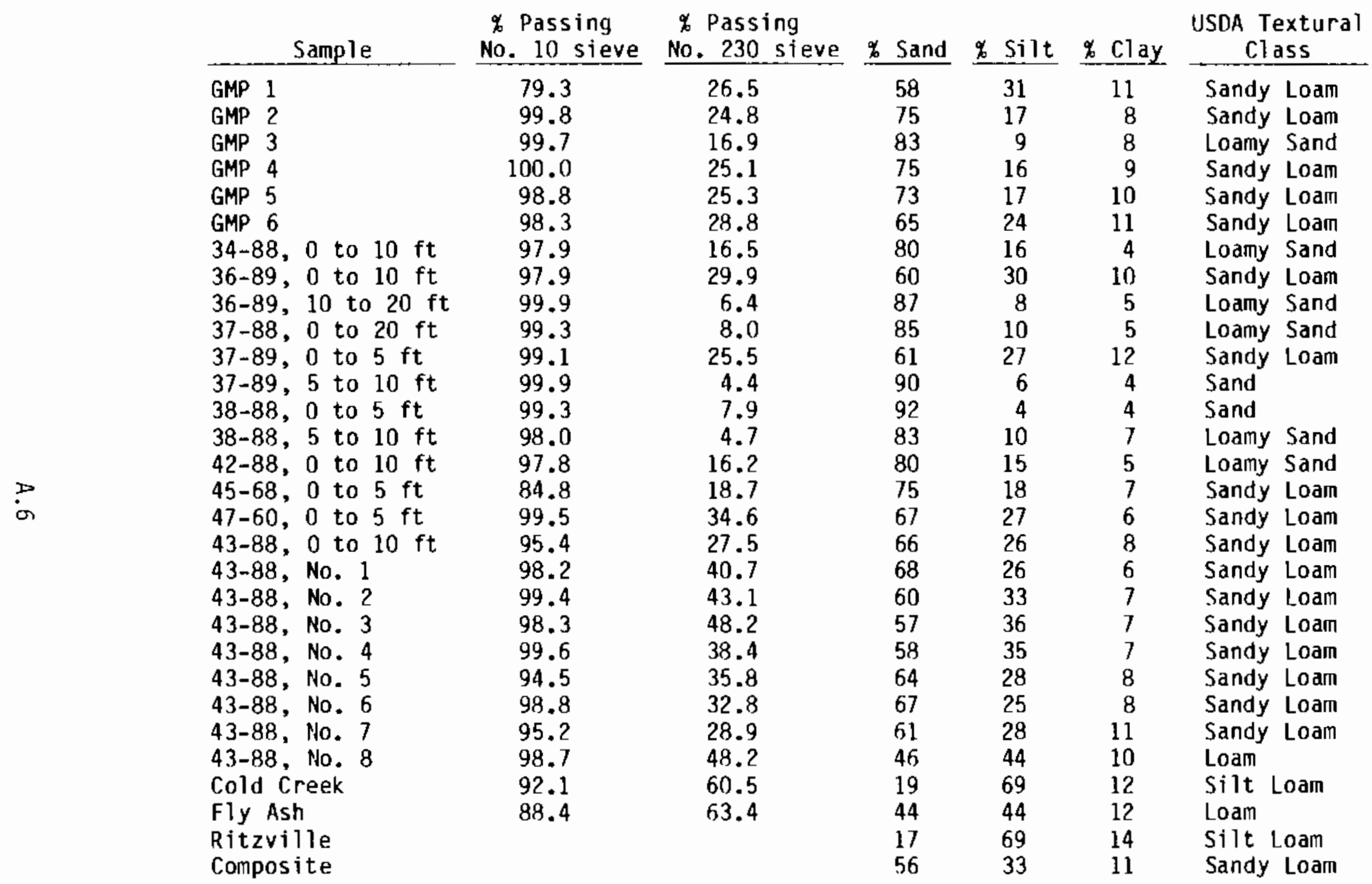


samples were analyzed for a complete distribution curve, except for dispersion of the sample, by ASTM procedure D 422 (ASTM 1985). Sample dispersion was done using an ultrasonic homogenizer for more complete dispersion of the particles.

\section{A.2.4 Water Storage}

Water storage in a $150-\mathrm{cm}$ profile was estimated using the following equation:

$$
W S=\left(\theta_{0.1}-\theta_{3.0}\right) \times 150 \mathrm{~cm}
$$

where $W S=$ water storage in $\mathrm{cm}$ of water

$\theta_{0.1}=$ volumetric water content at 0.1 bar pressure

$\theta_{3.0}=$ volumetric water content at 3.0 bar pressure.

\section{A.3 GRAVEL MOISTURE CHARACTERISTIC}

During modeling, we treated the material making up the $3.6 \mathrm{~m}$ gravel layer as a gravel that is $0.6-$ to $1.3-c m$ dia with an average pore diameter of $1.0 \mathrm{~cm}$ (the actual material diameter will be 10 to $25 \mathrm{~cm}$ ). Al though this material more closely represents the material that will go between the soil layer and lower gravel layer, it should provide a good estimate of how the overall system works.

Because we were unable to locate moisture characteristic data for such material, we estimated the data using the capillary pore model

$$
h=\frac{2 \gamma \cos \alpha}{g\left(\rho_{1}-\rho_{g}\right) r}
$$

where $\quad h=$ suction head or capillary pressure, $\mathrm{cm}$

$$
\begin{aligned}
\gamma= & \text { surface tension, } 72.7 \mathrm{~g} / \mathrm{s}^{2} \\
\alpha= & \text { contact angle between } 1 \text { iquid and solid, assumed to be zero } \\
g= & \text { gravity constant, } 980 \mathrm{~cm} / \mathrm{s}^{2} \\
\rho_{1}, \rho_{g}= & \text { density of } 1 \text { iquid and gas, respectively, with } \rho_{1}=1 \mathrm{~g} / \mathrm{cm}^{3} \\
& \text { and } \rho_{g} \approx 0 \\
r= & \text { radius of pore, } 1.0 / 2=0.5 \mathrm{~cm}
\end{aligned}
$$


The porosity of 0.6 - to $1.3-\mathrm{cm}$ dia gravel was determined in the laboratory as 0.419 . Using the pore model and the porosity, we calculated a portion of the moisture characteristic data in Table A.4.

Based on the pore model, the pore water in gravel would drain completely at a suction head value of $0.3 \mathrm{~cm}$. Before that point is reached, however, the pore model loses its applicability as water retention becomes a function of surface area. Above a suction head of $0.27 \mathrm{~cm}$, therefore, we have relied entirely on our experience to estimate moisture characteristic data as shown in Table A.4.

TABLE A.4. Gravel Moisture Characteristic Data

\begin{tabular}{|c|c|c|}
\hline $\begin{array}{l}\text { Suction } \\
\text { Head } \\
\text { (cm) }\end{array}$ & $\begin{array}{l}\text { Moisture } \\
\text { Content } \\
\left(m^{3} m^{-3}\right) \\
\end{array}$ & $\begin{array}{c}\text { Method of } \\
\text { Determination }\end{array}$ \\
\hline $\begin{array}{l}0.01 \\
0.019 \\
0.037 \\
0.074 \\
0.148 \\
0.165 \\
0.185 \\
0.212 \\
0.247 \\
0.270 \\
0.21 \\
0.40 \\
0.62 \\
1.0 \\
2.0 \\
6.0 \\
10.0 \\
1000.0\end{array}$ & $\begin{array}{l}0.419 \\
0.410 \\
0.402 \\
0.383 \\
0.343 \\
0.333 \\
0.319 \\
0.298 \\
0.261 \\
0.226 \\
0.190 \\
0.150 \\
0.110 \\
0.080 \\
0.050 \\
0.030 \\
0.027 \\
0.020\end{array}$ & $\begin{array}{c}\text { measured pore } \\
\text { model estimate } \\
" 1 \\
" \\
" \\
" \\
" \\
" \\
\text { " } \\
\text { empirical estimate } \\
" \\
" \\
" \\
" \\
" \\
"\end{array}$ \\
\hline
\end{tabular}




\section{REFERENCES}

ASTM, 1985. Annual Book of ASTM Standards, Section 4: Construction. Vo 1. 04.08. American Society of Testing Materials, Filladelphia, Pennsylvania.

Kl ute, A. 1965. "Laboratory Measurement of Hydraulic Conductivity of Saturated So i1." In Methods of Soil Analysis, Part 1, ed. C. A. BT ack, pp. 210-222. American Society of Agronomy, Madison, Wisconsin.

Richards, L. A. 1965. "Physical Condition of Water in Soil." In Methods of Soil Analysis, Part 1, ed. C. A. Black, pp. 128-137. American Society of Agronomy, Madison, Wisconsin. 
$\checkmark$ 
APPENDIX B

SIMULATION RESULTS 
TABLE B.1. Simulation Run Identification

\begin{tabular}{|c|c|c|c|c|}
\hline $\begin{array}{c}\text { Case } \\
\text { Identifier } \\
\end{array}$ & $\begin{array}{c}\text { Annual } \\
\text { Rainfal } \\
\text { (cm) } \\
\end{array}$ & Plants & $\begin{array}{l}\text { So } 11 / \text { Gravel } \\
\text { Surface Layer } \\
\text { Thickness } \\
\text { (cm) }\end{array}$ & $\begin{array}{c}\text { Impermeable } \\
\text { Layer }\end{array}$ \\
\hline COAR & 16.0 & yes & 0.0 & no \\
\hline CDARNP & 16.0 & no & 0.0 & no \\
\hline WCOAR & 30.1 & yes & 0.0 & no \\
\hline WCOARNP & 30.1 & no & 0.0 & no \\
\hline COMP & 16.0 & yes & 0.0 & no \\
\hline COMPNP & 16.0 & no & 0.0 & no \\
\hline WCOMP & 30.1 & yes & 0.0 & no \\
\hline WCOMPNP & 30.1 & no & 0.0 & no \\
\hline RITZ & 16.0 & yes & 0.0 & no \\
\hline RITZNP & 16.0 & no & 0.0 & no \\
\hline WRITZ & 30.1 & yes & 0.0 & no \\
\hline WR ITZNP & 30.1 & no & 0.0 & no \\
\hline COMPGR & 16.0 & yes & 30.0 & no \\
\hline COMPGRNP & 16.0 & no & 30.0 & no \\
\hline WCOMPGR & 30.1 & yes & 30.0 & no \\
\hline WCOMPGRNP & 30.1 & no & 30.0 & no \\
\hline RITZGR & 16.0 & yes & 30.0 & no \\
\hline RITZGRNP & 16.0 & no & 30.0 & no \\
\hline WRITZGR & 30.1 & yes & 30.0 & no \\
\hline WR I TZGRNP & 30.1 & no & 30.0 & no \\
\hline WADMIX75 & 30.1 & no & 7.5 & no \\
\hline WAOMIXI5 & 30.1 & no & 15.0 & no \\
\hline IMPERM & 16.0 & no & 30.0 & yes \\
\hline WIMPERM & 30.1 & no & 30.0 & yes \\
\hline
\end{tabular}


TABLE B.2. Final Simulation Year Results (INFIL is infiltration, EVAP is Evaporation, TRANSP is Transpiration, RUNOFF is Precipitation that did not infiltrate, and DRAIN is drainage. A positive flux at $1.5 \mathrm{~m}$ indicates downward fiow. All units are centimeters of water.)

Final Simulation Year Results

\begin{tabular}{|c|c|c|c|c|c|c|c|c|c|}
\hline Case & $\begin{array}{l}\text { Initial } \\
\text { Storage } \\
\end{array}$ & $\begin{array}{c}\text { Finat } \\
\text { Storage }\end{array}$ & $\begin{array}{c}\text { Delta } \\
\text { Storage }\end{array}$ & INF I & EVAP & TRANSP & RUNOFF & DRAIN & $\begin{array}{l}\text { Fiux at } \\
1.5 \mathrm{M} \\
\end{array}$ \\
\hline OAR & 33.870 & 28.623 & -2.085 & 15.968 & 9.783 & 8.306 & 0.0 & 0.0 & 0.0 \\
\hline JARNP & 33.870 & 45.275 & 0.0 & 15.968 & 15.963 & 0.0 & 0.0 & .0 & 0.0 \\
\hline ICOAR & 33.870 & 35.453 & +0.081 & 29.961 & 16.412 & 13.409 & 0.177 & & 0.0 \\
\hline COARNP & 43.231 & 61.122 & 0.0 & 30.138 & 27.081 & 0.0 & 0.0 & 3050 & 3.059 \\
\hline$M P$ & . & 3 & 0 & & & & & & 0.0 \\
\hline DMPNP & 42.974 & 60.054 & 0.0 & 15.654 & 15.233 & & 0.314 & 0.421 & 0.422 \\
\hline COMP & $42 \cdot 514$ & 26.486 & -8.017 & 25.440 & 10.733 & 771 & 98 & .0 & 0.006 \\
\hline СОMРNP & 42974 & 64.030 & -0.001 & 26.145 & 22.573 & & 3.993 & 3.683 & 3.681 \\
\hline ITZ & 49.196 & 612 & -0.947 & 15 & 9.590 & 25 & 0.0 & 0 & 0.003 \\
\hline TZNP & 1 & 39.751 & -0.399 & 15.968 & 16.369 & & 0.0 & .0 & -0.001 \\
\hline RITZ & 96 & 28.678 & -0.170 & 30. & 12. & 18 & 0.0 & 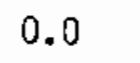 & -0.022 \\
\hline RITZNP & 196 & 52.567 & -0.005 & 30.138 & 30.144 & & 0.0 & .0 & 0.0 \\
\hline 年 & & 242 & -0.686 & 1 & 80 & & 0. & $-x_{-1}$ & 0.0 \\
\hline OMPGR NP & 40.328 & 59.369 & +0.008 & 15.968 & 14.241 & 0.0 & 0.0 & 1.720 & 1.724 \\
\hline WCOMPGR & 40.328 & 27.529 & -7.203 & 28.771 & 11.274 & 24.704 & 1.36 & 0.0 & -0.006 \\
\hline ICOMPGR & 8 & 64.317 & +0.003 & 39 & 81 & & & 6 & 7.795 \\
\hline RITZGR & 48.194 & 31.158 & -1.840 & 15.968 & 9.901 & 7.908 & 0.0 & 0.0 & -0.003 \\
\hline RITZGRNP & 48.194 & 50.148 & +0.008 & 15.968 & 15.951 & 0.0 & 0.0 & 0.0 & 0.0 \\
\hline WRITZGR & 48.194 & 33.145 & -7.578 & 29.767 & 12.484 & 24.872 & 0.371 & 0.0 & -0.010 \\
\hline NR ITZGRNP & 48.194 & 71.171 & +0.003 & 29.795 & 28.069 & 0.0 & 0.343 & 1.72 & 1.729 \\
\hline WADMIX75 & 65.297 & 66.322 & +0.011 & 29.681 & 22.054 & 0.0 & 0.407 & 1.100 & 7.703 \\
\hline WADMIX15 & 65.083 & 65.696 & 0.0 & 29.728 & 22.015 & 0.0 & $0.41 D$ & 7.729 & 7.728 \\
\hline IMPERM & 45.526 & 56.586 & +0.005 & 15.968 & 15.963 & 0.0 & 0.0 & 0.0 & D. 0 \\
\hline WIMPERM & 51.565 & 62.036 & 0.0 & 28.843 & 28.846 & 0.0 & 1.295 & 0.0 & 0.0 \\
\hline
\end{tabular}

Note: The final water table thickness was $80.0 \mathrm{~cm}$ for Case IMPERM and $124 \mathrm{~cm}$ for Case WIMPERM. 


\section{DISTRIBUTION}

No. of

Copies

OFFSITE

M. J. Barainca, Program Manager

Low-Level Waste Management Program

Idaho Operations of fice

U.S. Department of Energy

55D Second Street

Idaho Falls, ID 83401

R. Boland

Waste Managenent Project

Office

Nevada Operations Office

U.S. Department of Energy

P.0. Box 14100

Las Vegas, NV 89114

T. C. Chee

R\&D and Byproducts Division

DP-123 (GTN)

U.S. Department of Energy

Washington, DC 20545

B. W. Church, Director Health Physics Division Nevada Operations office

U.S. Department of Energy

P.0. Box 14100

Las Vegas, NV 89114

F. Gorup, Program Manager

Nuclear Waste Management Group

Chicago Operations office

U.S. Department of Energy

9800 South Cass Avenue

Argonne, IL 60439

J. J. Jicha, Director

R\&O and Byproducts Division

DP-123 (GTN)

U.S. Department of Energy

Washington, OC 20545
No. of

Copies

0. D. Markham

U.S. Department of Energy

Idaho Operations office

Radiological and Environmental

Sciences Laboratory

Idaho Falls, IU 83401

D. B. Leclaire, Director

Office of Defense Waste and Byproducts Management

DP-12 (GTN)

U.S. Department of Energy

Washington, DC 20545

M. H. McFadden

TRU Waste Program Manager

Waste Management and Transportation Development Division

U.S. Department of Energy

P. 0 . Box 5400

Albuquerque, NM 87115

R. L. Walters

Ecological Research Division ER-75

Office of Health and Environmental Research, OER

U.S. Department of Energy

Washington, DC 20545

DOE Technical Information Center

Technical Library

Argonne National Laboratory

Argonne, IL 60439

Peter Colombo, Group Leader

Nuclear Waste Research

Brookhaven National Laboratory

Building 701

Upton, NY 11973 
No. of

Copies

Marty Mifflin

Desert Research Institute

1500 E. Tropicana Ave.

Suite 210

Las Vegas, NV 89109

E. A. Jennrich

Low-Level Management

Program

EG\&G Idaho, Inc.

P.0. Box 1625

Idaho Falls, Idaho 83415

Environmentai Protection Agency

Technology Assessment Division

Office of Radiation Programs

Washington, D.C. 20460

Technical Library

Idaho National Engineering Laboratory

Idaho Falls, Idaho 83401

Technical Library

Los Alamos National Laboratory

Los Al amos, New Mexico 87545

T. E. Hakonson

Los Al amos National Laboratory

Los Al amos, NM 87545

J. W. Nyhan

Los Al amos National Laboratory

P. 0. Box 1663

Los Alamos, NM 87545

National Academy of Sciences

National Research Council

2101 Constitution Avenue

Washington, DC 20418

P. J. Wierenga

Department of Soil Science

New Mexico State University

Las Cruces, NM 88004
No. of

Copies

\author{
Dan Stephens \\ Department of Geosciences \\ New Mexico Tech \\ 50 Corro, NM 87801 \\ Technical Library \\ Oak Ridge Nationa? Laboratory \\ Oak Ridge, Tennessee 37830 \\ E. W. Kenda11 \\ Waste Management Project Manager \\ REECO \\ P.0. Box 642 \\ Mercury, NV 89023 \\ J. J. Blakeslee, Program Manager \\ Nuclear Waste Processing \\ Rockwel1 International \\ P.0. Box 464 \\ Golden, C0 80401 \\ C. E. Wickland \\ Manager, Waste Operations \\ Rockwel 1 Internationa 1 \\ Rocky Flats PIant \\ P.0. Box 464 \\ Golden, C0 80401 \\ J. C. Corey \\ Savannah River Laboratory \\ P.0. Box A \\ Aiken, SC 29801 \\ I. W. Marine \\ Savannah River National \\ Laboratory \\ Box A \\ Aiken, SC 29801 \\ Technical Library \\ Savannah River National \\ Laboratory \\ Aiken, SC 29081
}


No. of

Copies

A. W. Warrick

Department of Soils, Water, and Engineering

University of Arizona

Tuscon, AZ 85721

E. M. Romney

University of California

at Los Angeles

Westwood, CA 96137

D. Hillel

12A Stockbridge $\mathrm{Ha} 11$

University of Massachusetts

Amherst, MA 01003

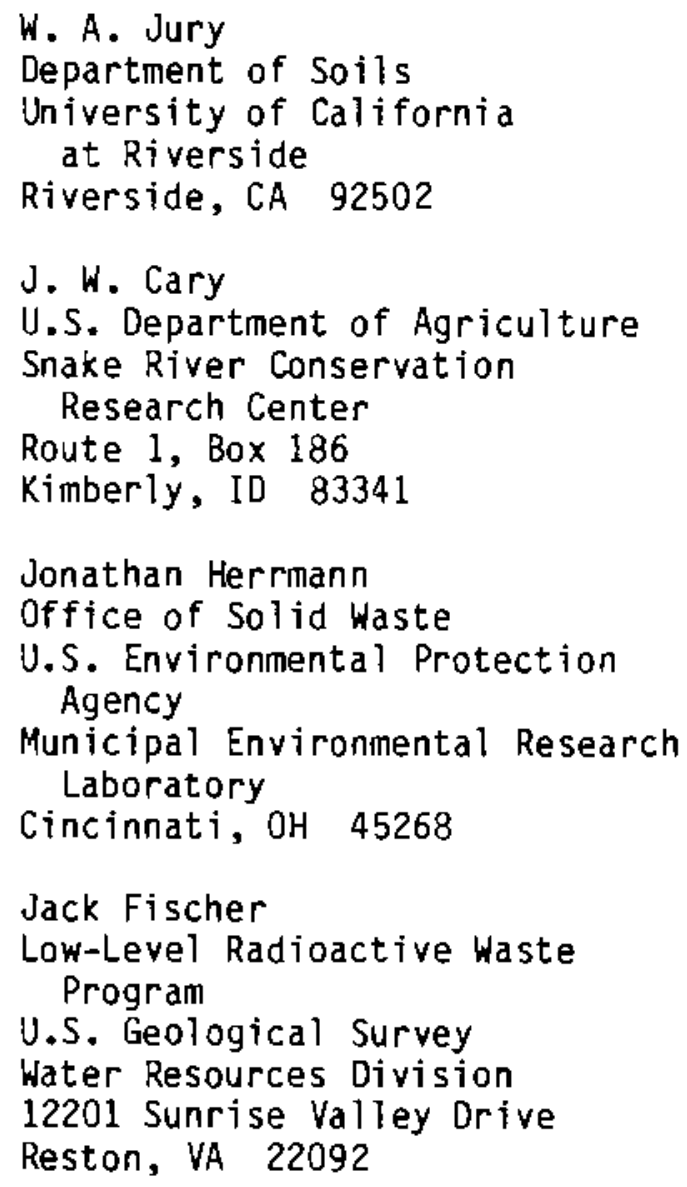

No. of

Copies

I. J. Winograd

U.S. Geological Survey

National Center - Mail Stop 432

Reston, VA 22092

E. P. Weeks

U.S. Geological Survey

Federal Center Majl Stop 413

Denver, CO 80225

E. O'Donnel!

Earth Sciences Branch

Division of Health, Siting and Waste Management Research

U.S. Nuclear Regulatory Commission

Washington, DC 20555

F. Swanberg

Division of Health, Siting and Waste Management Research

U.S. Nuclear Regulatory Commission

Washington, DC 20555

T. J. Nicholson

Division Health, Siting and Waste Management

U.S. Nuclear Regulatory Commission

MS 1130 SS

Washington, DC 20555

Jeanne Rense 1

$\mathrm{Hi}$-Level Waste Management

Washington State Department of Ecology

Pu II

01 ympia, WA 98504

G. S. Campbel 1

Washington State University

Pullman, WA 99164 
No. of

Copies

ONSITE

Hanford Engineering Development

Laboratory

R. E. Lerch

6 Richland Operations Office

E. A. Bracken

R. A. Holten

N. T. Karagianes

H. E. Ranson

J. D. White

J. K. W. Wukelic

21 Rockwel1 Hanford Operations

M. R. Adams

3. F. Albaugh

S. Baker

L. C. Brown

W. H. Chapman-Riggsbee

C. DeFigh-Price

W. F. Heine

W. A. Jordan

G. G. Meade

S. J. Phillips

R. D. Prosser

J. F. Relyea

J. H. Roecker

R. C. Routson

D. L. Sanders

W. W. SchuTz

J. C. Sonnichsen

S. A. Wiegman

G. F. Williamson

N. R. Wing

D. E. Wood
No. of

Copies

2 Unjted Nuclear Industries

K. A. Gano

D. R. Pratt

45

Pacific Northwest Laboratory

P. A. Beedlow

3. B. Burnham

W. Conbere

D. W. Oragnich

M. J. Fayer (10)

G. W. Gee (5)

M. J. Graham

H. A. Haerer

M. S. Hanson

J. N. Hartley

P. C. Hays

P. R. Heller

$T$. L. Jones

C. T. Kincaid

R. R. Kirkham

G. V. Last

I. C. Nelson

A. E. Reisenauer

L. E. Rogers

R. L. Skaggs

R. J. Serne

C. S. Simmons

D. R. Simpson

J. A. Stottlemyre

G. P. Streije

Technical Information (5)

Publishing Coordination (2) 